This document is confidential and is proprietary to the American Chemical Society and its authors. Do not copy or disclose without written permission. If you have received this item in error, notify the sender and delete all copies.

\title{
Dynamic coupling of mass transfer and chemical reaction for Taylor flow along a serpentine microchannel
}

\begin{tabular}{|r|l|}
\hline Journal: & Industrial \& Engineering Chemistry Research \\
\hline Manuscript ID & ie-2020-00014t.R4 \\
\hline Danuscript Type: & Article \\
\hline Author: & 21-Apr-2020 \\
\hline & $\begin{array}{l}\text { Zubmitted by the List of Authors: } \\
\text { Zhang, Peng; Yantai University } \\
\text { Zngineering } \\
\text { Lü, Hongying; College of Chemistry and Chemical Engineering, Yantai } \\
\text { University, } \\
\text { Zhao, Yuchao; Yantai University, College of Chemistry \& Chemical } \\
\text { Engineering }\end{array}$ \\
\hline
\end{tabular}

\section{SCHOLARONE Manuscripts}


4

\section{5}

\section{Dynamic coupling of mass transfer and chemical reaction for Taylor}

3 Yufei Zhou ${ }^{\mathrm{a}, \xi}$, Chaoqun Yao ${ }^{\mathrm{b}, \xi}$, Peng Zhang ${ }^{\mathrm{a}}$, Xunli Zhang ${ }^{\mathrm{c}}$, Hongying Lï ${ }^{\mathrm{a}}$, Yuchao Zhao ${ }^{\mathrm{a}, *}$

${ }^{a}$ Shandong Collaborative Innovation Center of Light hydrocarbon transformation and utilization, School of Chemistry \& Chemical Engineering, Yantai University, Yantai 264005, China

${ }^{\mathrm{b}}$ Dalian National Laboratory for Clean Energy, Dalian Institute of Chemical Physics, Chinese Academy of Sciences, Dalian116023, China

c School of Engineering \& Institute for Life Sciences, University of Southampton, Southampton SO17 1BJ, UK

$\xi^{\xi}$ The authors contribute equally to the paper

\section{ABSTRACT}

The characteristics of multiphase dynamic mass transfer play a big role in gaining understanding and controllability of gas-liquid two-phase chemical absorption processes. In the present work, dynamic coupling of mass transfer and chemical reaction for Taylor flow in a serpentine microchannel was investigated by an online method. The dynamic changes of gas bubbles, key mass transfer parameters (i.e., $k_{L} a$, $k_{L}$ and $\left.a\right)$ and the enhancement factor were measured and calculated, where three changing stages were found under different operating conditions of $Q_{G}(2-5.5 \mathrm{~mL}), Q_{L}$ (1-2.5 $\mathrm{mL}), W_{M E A}(1-3 \mathrm{wt} \%)$. Based on the experimental results, a modified van Baten's model was proposed to predict mass transfer performance for both $\mathrm{CO}_{2}-\mathrm{H}_{2} \mathrm{O}$ and $\mathrm{CO}_{2}$-MEA systems, and the correlation coefficients were 0.95 and 0.96 , respectively. The correlations also suggested the net physical mass transfer performance in $\mathrm{CO}_{2}$-MEA system could be reasonably separated from the chemical absorption process.

\footnotetext{
* Corresponding Author. Tel: +86 5356903386.

E-mail address: yczhao@ytu.edu.cn (Y. Zhao).
} 


\section{1. INTRODUCTION}

2 Among the current technologies for the removal of $\mathrm{CO}_{2}$, chemical absorption with

3 monoethanolamine (MEA) solution has been the most widely used one. ${ }^{1,2}$ Although

4 great efforts have been made to develop gas-liquid contactors for higher process

5 efficiency, the amount of absorbent used, the energy consumption and the equipment

6 investment are still far from satisfactory. ${ }^{3,4}$. Generally, the efficiency of gas-liquid

7 contactors is determined by gas-liquid mass transfer performance, where the dynamic

8 change (e.g., formation, growth, shrinkage, collapse and coalescence) of bubbles

9 plays an important role. Due to the complex hydrodynamics of gas bubble populations,

10 there still remains challenges to measure the instantaneous volumetric mass transfer

11 coefficient with high spatiotemporal precision. ${ }^{5,6}$

12 In recent years, microchannel contactors have been developed into powerful tools

13 for measuring the volumetric mass transfer coefficient, owing to its small

14 characteristic dimension, large surface-to-volume ratio and controllable gas-liquid

15 flow patterns..$^{7-14}$ Berčič and Pintar put forward an empirical correlation based on a 16 unit cell model for predicting the liquid side volumetric mass transfer coefficient $\left(k_{L} a\right)$

17 in methane-water system under Taylor flow; they found that $\left(k_{L} a\right)$ was mostly 18 determined by the liquid slug length and velocity. ${ }^{15}$ van Baten and Krishna 19 investigated mass transfer from Taylor bubbles to the liquid phase by computational 20 fluid dynamics, and found that $k_{L} a$ was determined by the sum of the contributions of 21 the two bubble caps and the film surrounding the bubble. ${ }^{16}$ Yue et al. examined $\mathrm{CO}_{2}$ 22 absorption in water and $\mathrm{NaHCO}_{3} / \mathrm{Na}_{2} \mathrm{CO}_{3}$ buffer solution, and proposed an improved 
1 empirical correlation for determining $k_{L} a \cdot^{17,18} \mathrm{Li}$ et al. studied the effects of flow rates

2 on $k_{L} a$ in Taylor flow with $\mathrm{CO}_{2}$-MEA system. ${ }^{19}$ Recently, Chu et al. investigated

3 experimentally the mass transfer characteristics of $\mathrm{CO}_{2}$ absorption into aqueous

4 solution of ionic liquid in microchannel and proposed a dimensionless correlation to

5 predicting $k_{L} a \cdot{ }^{20}$ In these studies, $k_{L} a$ was generally assumed to be constant across the

6 entire reactor under given operating conditions. However, the dynamic shrinkage of

7 Taylor bubble along the microchannel was disregarded.

8 To address this issue, Cubaud et al. measured the evolution of $\mathrm{CO}_{2}$ bubble size with

9 physical solvents in long serpentine microchannels by tracking individual bubbles

10 along the flow direction to establish the functional relationship between bubble size

11 and velocity. ${ }^{21,22}$ Abolhasani et al. developed an automated microfluidic platform to

12 determine $\mathrm{CO}_{2}$ solubility, $k_{L} a$, as well as the reducing rate of Taylor bubbles, which

13 could be translated into mass transfer performance. ${ }^{23}$ Similar effort was made by Tan

14 et al. to measure the changes of gas bubble volume versus flowing distance, which

15 was beneficial to further estimation of $k_{L} a{ }^{24}$ By developing a unit cell model, Yao et

16 al. built a relation between $k_{L} a$ and the reducing rate of $\mathrm{CO}_{2}$ bubbles, realizing direct

17 measurement of $k_{L} a$ through monitoring $\mathrm{CO}_{2}$ bubbles size. ${ }^{25}$ Zhang et al. used a

18 similar model to characterize gas-liquid mass transfer for $\mathrm{CO}_{2}-\mathrm{H}_{2} \mathrm{O}$ system. ${ }^{14}$

19 Although these investigations shed considerable light on the dynamic characteristics

20 of the gas-liquid mass transfer process, these findings were limited to physical

21 absorption and differed from chemical absorption processes.

22 There have been efforts made in examining the mass transfer of $\mathrm{CO}_{2}$ chemical 
1 absorption into aqueous MEA solutions for Taylor flow along microchannels. ${ }^{19,26,27}$

2 Zhu et al. found the bubble length decreased exponentially along the microchannel

3 due to $\mathrm{CO}_{2}$ reactive absorption, and a turning point existed in the flowrate ratio of gas

4 and liquid phases for different MEA concentrations ${ }^{26}$. A correlation for predicting $k_{L} a$

5 was also proposed by integrating the enhancement factor of chemical reaction ${ }^{27}$.

6 However, these studies were still limited to treating $k_{L} a$ as constant. Moreover, the

7 dynamic change of mass transfer enhancement due to chemical reaction was not

8 considered.

9 Based on the above analysis, the aim of the present work was to quantitatively 10 characterize the dynamic coupling of mass transfer and chemical reaction under 11 Taylor flow of the $\mathrm{CO}_{2}$-MEA system along a microchannel. An online imaging 12 technique with a high-speed camera and a stereo microscope was employed to 13 measure the evolution of the geometry and movement of gas bubbles. The dynamic 14 changes were quantified in terms of $k_{L} a$, liquid phase mass transfer coefficient $\left(k_{L}\right)$, 15 specific interfacial area $(a)$ and enhancement factor $(E)$. A theoretical model was established for determining $E$. In order to predict the local mass transfer performance, a model was proposed for both $\mathrm{CO}_{2}-\mathrm{H}_{2} \mathrm{O}$ and $\mathrm{CO}_{2}$-MEA systems. These findings would provide strong foundation for designing and optimizing gas-liquid microchannel contactors towards high process performance.

\section{EXPERIMENTAL SECTION}

The experimental setup is shown schematically in Figure 1(a). Two high pressure syringe pumps (LSP01-1BH, Longer) and two stainless steel syringes (50 mL, Longer) 
1 were used to deliver gas and liquid, respectively. The gas and liquid flow rates were

2 calibrated by the weighting method and an automated electronic soap film flowmeter

3 (GL-101B, 0.1-100 mL/min, accuracy 1\%, Beijing Beifen Sanpu, China), respectively.

$4 \quad \mathrm{CO}_{2}(99.999$ vol\%) and aqueous MEA solution (analytical grade, Sinopharm

5 Chemical Reagent Co., Ltd.) were used as the working fluids. The operating

6 temperature was set at $25{ }^{\circ} \mathrm{C}$. The pressure drop across the flow channel was

7 measured by a pressure transducer (DMP305X, 0 50kPa, accuracy 0.075\%, LEEG,

8 China). Across the whole length $(200 \mathrm{~mm})$ of the microchannel, the overall pressure

9 drop was found to be minimal $(<6.6 \mathrm{kPa})$ suggesting that the evolution of the local

10 pressure along the microchannel was insignificant. Therefore, a linear correlation was

11 used to represent $P_{\mathrm{CO} 2}$ as a function $X$ in this work. The concentrations of the aqueous

12 MEA solution were set at four levels, i.e., 1.0, 1.5, 2.0 and $3.0 \mathrm{wt} \%$. The main reason

13 for choosing the MEA concentration range (1.0-3.0 wt \%) in this study was to enable

14 practically measuring the gas-liquid mass transfer performance, although it was

15 relatively lower than that in industrial applications. The dynamic changes of $\mathrm{CO}_{2}$

16 bubbles were recorded by a high-speed camera (Phantom R311, $3200 \mathrm{fps}$ ) mounted on

17 a stereo microscope (Olympus SZX 16). The resolution and exposure time were 1280

$18 \times 800$ pixels and $490 \mu$ s, respectively.

19

20

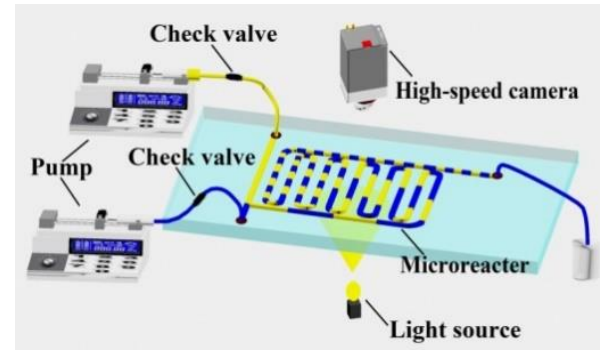

(a)

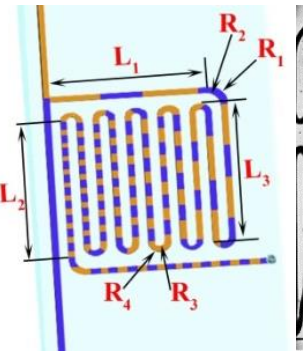

(b)

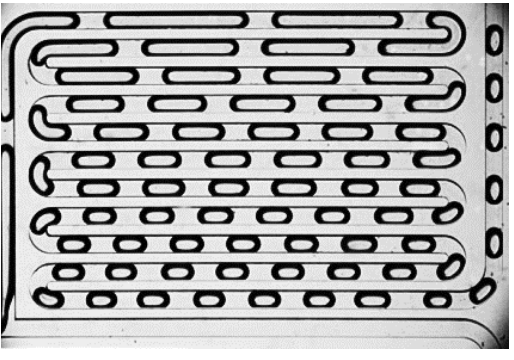

(c) 
1 Figure 1. T-junction microchannel and gas-liquid mass transfer system (a) Schematic of the experimental setup; (b) T-junction microchannel; (c) Typical captured image. Figure 1(b) illustrates the layout design of the microchannel with a T-junction followed by a long serpentine microchannel. The design parameters (width, depth,

5 length, and radius) for different sections of the microchannel are summarized in Table

6 1. The microchannels were fabricated on PMMA plates (A grade, 92\% of light

7 transmittance, ShenZhen HuiLi Acrylic Products Co., Ltd.) by precision milling and

8 sealed by thermal sealing. Figure 1(c) shows a snapshot captured by a high-speed

9 camera focused on the main area covering all 12 serpentine microchannels. 1000

10 images were taken from each set of experiment, and the changes in bubble length and

11 velocity along the microchannel were analyzed by Matlab image analysis program.

12 Table 1. Geometries (mm) of microchannel in Figure 1(b)

\begin{tabular}{cccccccccc}
\hline Width $/ w$ & Depth $/ h$ & $\mathrm{~L}_{1}$ & $\mathrm{~L}_{2}$ & $\mathrm{~L}_{3}$ & $\mathrm{R}_{1}$ & $\mathrm{R}_{2}$ & $\mathrm{R}_{3}$ & $\mathrm{R}_{4}$ & Total length/L \\
\hline 0.6 & 0.6 & 9.43 & 14.28 & 13.96 & 1.0 & 1.5 & 0.2 & 0.8 & 181.13 \\
\hline
\end{tabular}

13

\section{PROCESS ANALYSIS AND MODELING}

\subsection{Reaction Mechanisms and Mass Transfer Process Analysis}

The chemical reaction of $\mathrm{CO}_{2}$ with aqueous MEA solution can be interpreted by either the zwitterion mechanism ${ }^{28,29}$ or the termolecular mechanism. ${ }^{30,31}$ The former

was more commonly used. ${ }^{32,33}$

Zwitterion formation:

$$
\mathrm{CO}_{2}+\mathrm{RNH}_{2} \underset{\mathrm{k}_{-1}}{\stackrel{\mathrm{k}_{1}}{\rightleftharpoons}} \mathrm{RNH}_{2}^{+} \mathrm{COO}^{-}
$$

Zwitterion deprotonation:

$$
\mathrm{RNH}_{2}^{+} \mathrm{COO}^{-}+\mathrm{RNH}_{2} \stackrel{\mathrm{k}_{2}}{\longrightarrow} \mathrm{RNHCOO}^{-}+\mathrm{RNH}_{3}^{+}
$$


3 where $\mathrm{R}$ denotes $-\mathrm{CH}_{2} \mathrm{CH}_{2} \mathrm{OH}$.

4 Combining Eqs. (1)-(4), the following expression was obtained based on the 5 assumption of quasi-steady state for the zwitterion concentration.

$$
\mathrm{r}_{\mathrm{CO}_{2}}=\frac{-\mathrm{k}_{1} \mathrm{C}_{\mathrm{CO}_{2}} \mathrm{C}_{\mathrm{MEA}}}{1+\frac{\mathrm{k}_{-1}}{\mathrm{k}_{2} \mathrm{C}_{\mathrm{MEA}}+\mathrm{k}_{3} \mathrm{C}_{\mathrm{H}_{2} \mathrm{O}}+\mathrm{k}_{4} \mathrm{C}_{\mathrm{OH}^{-}}}}
$$

7 Generally, the zwitterion deprotonation was much faster than its decomposition, i.e., $8 \quad \mathrm{k}_{-1} /\left(\mathrm{k}_{2} \mathrm{C}_{\mathrm{MEA}}+\mathrm{k}_{3} \mathrm{C}_{\mathrm{H}_{2} \mathrm{O}}+\mathrm{k}_{4} \mathrm{C}_{\mathrm{OH}^{-}}\right)<<1$, then the rate of $\mathrm{CO}_{2}$ reaction with MEA could 9 be expressed by a simple second-order kinetics ${ }^{29,34}$ :

$$
-\mathrm{r}_{\mathrm{CO}_{2}}=\mathrm{k}_{1} \mathrm{C}_{\mathrm{CO}_{2}} \mathrm{C}_{\mathrm{MEA}}
$$

11 where $\mathrm{k}_{1}$ could be determined by the following empirical correlation: ${ }^{34}$

$$
\log _{10} \mathrm{k}_{1}=10.99-2152 / \mathrm{T}
$$

13 The mass balance for $\mathrm{CO}_{2}$ and MEA in the liquid phase based on two-film model was 14 written in the following,

15

$$
\left\{\begin{array}{l}
\mathrm{D}_{\mathrm{CO}_{2}}\left(\frac{\mathrm{d}^{2} \mathrm{C}_{\mathrm{CO}_{2}}}{\mathrm{dz}^{2}}\right)-\mathrm{k}_{1} \mathrm{C}_{\mathrm{CO}_{2}} \mathrm{C}_{\mathrm{MEA}}=0 \\
\mathrm{D}_{\mathrm{MEA}}\left(\frac{\mathrm{d}^{2} \mathrm{C}_{\mathrm{MEA}}}{\mathrm{dz}^{2}}\right)-\mathrm{k}_{1} \mathrm{C}_{\mathrm{CO}_{2}} \mathrm{C}_{\mathrm{MEA}}=0
\end{array}\right.
$$

Boundary conditions,

$$
\mathrm{z}=0, \mathrm{C}_{\mathrm{CO}_{2}}=\mathrm{C}_{\mathrm{CO}_{2}, \mathrm{i}}, \frac{\mathrm{dC}_{\mathrm{MEA}}}{\mathrm{dz}}=0 ; \mathrm{z}=\delta, \mathrm{C}_{\mathrm{CO}_{2}}=0, \mathrm{C}_{\mathrm{MEA}}=\mathrm{C}_{\mathrm{MEA}, \mathrm{L}}
$$
where $\mathrm{C}_{\mathrm{CO}_{2}, \mathrm{i}}$ was $\mathrm{CO}_{2}$ concentration at the gas-liquid interface, mol/m $/ \mathrm{m}^{3} ; \mathrm{C}_{\mathrm{MEA}, \mathrm{L}}$ was 
1 MEA concentration in the bulk liquid phase, mol/m $\mathrm{m}^{3} \cdot \mathrm{D}_{\mathrm{CO}_{2}}$ and $\mathrm{D}_{\mathrm{MEA}}$ were the

2 diffusion coeffcient of $\mathrm{CO}_{2}$ and MEA in aqueous MEA solution ${ }^{35}$, respectively, $\mathrm{m}^{2} / \mathrm{s}$.

3

$$
\begin{gathered}
\ln \mathrm{D}_{\mathrm{MEA}}=-13.275-2198.3 / \mathrm{T}-7.8142 \times 10^{-5} \mathrm{C}_{\mathrm{MEA}} \\
\mathrm{D}_{\mathrm{CO}_{2}}=\left(2.35+0.029837 \mathrm{C}_{\mathrm{MEA}}-9.7078 \times 10^{-3} \mathrm{C}_{\mathrm{MEA}}^{2}\right) \times 10^{-6} \exp \left(\frac{-2119-20.132 \mathrm{C}_{\mathrm{MEA}}}{\mathrm{T}}\right)
\end{gathered}
$$

5 For determining the enhancement factor, $E$, the analytical solution of van Krevelen 6 and Hoftijzer was adopted: ${ }^{36}$

7

8 where $H a$ and $\mathrm{E}_{\infty}$ as Hatta number and the infinite enhancement factor based on

9 two-film model, respectively, were expressed as,

10

where $\mathrm{k}_{\mathrm{L}}^{0}$ denoted the liquid side physical mass transfer coefficient, $\mathrm{m} / \mathrm{s}$.

\subsection{Modeling of Mass Transfer Coefficient}

A unit cell model for Taylor flow was used, ${ }^{14,16,25}$ as shown in Figure 2(a). There were a few assumptions associated with the model: (i) $\mathrm{CO}_{2}$ and aqueous MEA solution were well-mixed in each phase in a unit cell; (ii) the overall unit cell was considered as a plug flow; (iii) mass transfer and reaction from $\mathrm{CO}_{2}$ to aqueous MEA solution only happened within a unit cell; and (iv) each unit cell was independent.

$$
\mathrm{E}=\frac{\sqrt{\mathrm{Ha}^{2} \frac{\mathrm{E}_{\infty}-\mathrm{E}}{\mathrm{E}_{\infty}-1}}}{\tanh \sqrt{\mathrm{Ha}^{2} \frac{\mathrm{E}_{\infty}-\mathrm{E}}{\mathrm{E}_{\infty}-1}}}
$$




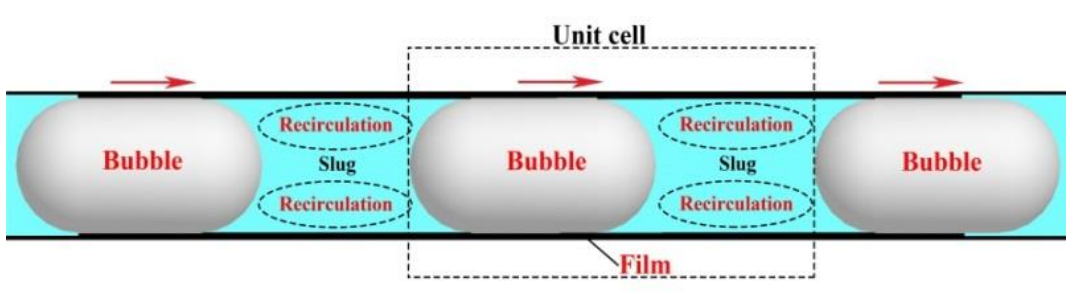

(a)

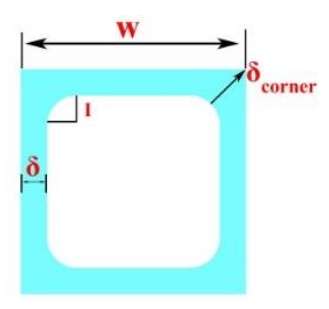

(b)

Figure 2. Schematic of typical gas-liquid two-phase Taylor flow in a microchannel. (a) Taylor bubble and slug in a unit cell. (b) Cross-section of Taylor bubble (not to scale). The mass balance of $\mathrm{CO}_{2}$ in a unit cell was described as the following.

$$
\frac{\mathrm{P}_{\mathrm{CO}_{2}}}{\mathrm{RT}} \cdot \frac{\mathrm{dV}_{\mathrm{B}}}{\mathrm{dX}} \mathrm{U}_{\mathrm{B}}=-\mathrm{k}_{\mathrm{L}} \mathrm{a}\left(\mathrm{C}_{\mathrm{CO}_{2}}^{*, \mathrm{~L}}-\mathrm{C}_{\mathrm{CO}_{2}}^{\mathrm{L}}\right)\left(\mathrm{V}_{\mathrm{B}}+\mathrm{V}_{\mathrm{L}}\right)
$$

where $\mathrm{P}_{\mathrm{CO}_{2}}$ was gas phase pressure which varied along the microchannel as a result of local pressure, $\mathrm{Pa} ; R$ was gas constant, $8.3145 \mathrm{~J} /(\mathrm{mol} \cdot \mathrm{K}) . T$ was operating temperature, $\mathrm{K} ; V_{B}$ was volume of $\mathrm{CO}_{2}$ bubble, $\mathrm{m}^{3} ; U_{B}$ was velocity of $\mathrm{CO}_{2}$ bubble, $\mathrm{m} / \mathrm{s}$, varying along the microchannel as a result of mass transfer and reaction; $\mathrm{X}$ was position along the serpentine microchannel, m. $k_{L}$ was liquid phase mass transfer coefficient, m/s. $a$ was specific interfacial area $\left(\mathrm{a}=\mathrm{A}_{\mathrm{S}} /\left(\mathrm{V}_{\mathrm{CO}_{2}}+\mathrm{V}_{\mathrm{L}}\right)\right), \mathrm{m}^{-1} \cdot A_{S}$ was effective mass transfer area, $\mathrm{m}^{2} . V_{L}$ was liquid phase volume including liquid slug and liquid film, $\mathrm{m}^{3} \cdot \mathrm{C}_{\mathrm{CO}_{2}}^{\mathrm{L}}$ was $\mathrm{CO}_{2}$ concentration in bulk liquid phase solution along the serpentine microchannel, mol/m $3{ }^{3} \cdot \mathrm{C}_{\mathrm{CO}_{2}}^{*, \mathrm{~L}}$ was saturated solubility of $\mathrm{CO}_{2}$ in aqueous MEA solution, $\mathrm{mol} / \mathrm{m}^{3}$, which was calculated based on Henry's Law,

$$
\mathrm{C}_{\mathrm{CO}_{2}}^{* \mathrm{~L}}=\frac{\mathrm{P}_{\mathrm{CO}_{2}}}{1000 \mathrm{H}_{\mathrm{CO}_{2}}^{\text {loaded }}}
$$

18 where $\mathrm{H}_{\mathrm{CO}_{2}}^{\text {loaded }}$ is Henry's constant of $\mathrm{CO}_{2}$ in the loaded aqueous MEA solution with $9 \mathrm{CO}_{2}, \mathrm{kPa} \cdot \mathrm{m}^{3} \cdot \mathrm{mol}^{-1}$, which can be estimated by $\mathrm{N}_{2} \mathrm{O}$ approximation method, ${ }^{37-41}$ 


$$
\begin{gathered}
\frac{\mathrm{H}_{\mathrm{CO}_{2}}^{\text {loaded }}}{\mathrm{H}_{\mathrm{N}_{2} \mathrm{O}}^{\text {load }}}=\frac{\mathrm{H}_{\mathrm{CO}_{2}}^{\mathrm{H}_{2} \mathrm{O}}}{\mathrm{H}_{\mathrm{N}_{2} \mathrm{O}}^{\mathrm{H}_{2} \mathrm{O}}} \\
\ln \left(\mathrm{H}_{\mathrm{N}_{2} \mathrm{O}}^{\mathrm{H}_{2} \mathrm{O}}\right)=-700.6501+14905.5017 / \mathrm{T}+126.3505 \ln \mathrm{T}-0.2267 \mathrm{~T}
\end{gathered}
$$

Henry's constant of $\mathrm{CO}_{2}$ in water was proposed by Versteeg and van Swaaij, ${ }^{42}$

$$
\mathrm{H}_{\mathrm{CO}_{2}}^{\mathrm{H}_{2} \mathrm{O}}=2.8249 \times 10^{3} \exp (-2044 / \mathrm{T})
$$

where $\mathrm{H}_{\mathrm{CO}_{2}}^{\text {loaded }}$ is Henry's constant of $\mathrm{CO}_{2}$ and $\mathrm{N}_{2} \mathrm{O}$ in the loaded aqueous MEA solution with $\mathrm{CO}_{2}, \mathrm{kPa} \cdot \mathrm{m}^{3} \cdot \mathrm{mol}^{-1} ; \mathrm{H}_{\mathrm{CO}_{2}}^{\mathrm{H}_{2} \mathrm{O}}$ and $\mathrm{H}_{\mathrm{N}_{2} \mathrm{O}}^{\mathrm{H}_{2} \mathrm{O}}$ are Henry's constants of $\mathrm{CO}_{2}$ and $\mathrm{N}_{2} \mathrm{O}$ in water, respectively, $\mathrm{kPa} \cdot \mathrm{m}^{3} \cdot \mathrm{mol}^{-1}$. For the loaded aqueous MEA solution system, the correlation of Henry's constant was proposed by Hartono et al.. ${ }^{41}$

$$
\begin{gathered}
\ln \left(\mathrm{H}_{\mathrm{N}_{2} \mathrm{O}}^{\text {loaded }}\right)=\ln \left(\Delta \mathrm{H}_{\mathrm{N}_{2} \mathrm{O}}^{\text {loaded }}\right)+\ln \left(\mathrm{H}_{\mathrm{N}_{2} \mathrm{O}}^{\text {unloaded }}\right) \\
\ln \left(\Delta \mathrm{H}_{\mathrm{N}_{2} \mathrm{O}}^{\text {loaded }}\right)=0.77 \mathrm{~m}_{\mathrm{MEA}}+0.033 \mathrm{~m}_{\mathrm{MEA}} \alpha \mathrm{T} \\
\ln \left(\mathrm{H}_{\mathrm{N}_{2} \mathrm{O}}^{\text {unloaded }}\right)=\ln \left(\Delta \mathrm{H}_{\mathrm{N}_{2} \mathrm{O}}^{\text {unloaded }}\right)+\varphi_{\mathrm{MEA}} \ln \left(\mathrm{H}_{\mathrm{N}_{2} \mathrm{O}}^{\mathrm{MEA}}\right)+\varphi_{\mathrm{H}_{2} \mathrm{O}} \ln \left(\mathrm{H}_{\mathrm{N}_{2} \mathrm{O}}^{\mathrm{H}_{2} \mathrm{O}}\right) \\
\ln \left(\Delta \mathrm{H}_{\mathrm{N}_{2} \mathrm{O}}^{\text {unloaded }}\right)=\left(1.9210-1.6792 \times 10^{-3} \mathrm{~T}+3.0951 \mathrm{~m}_{\mathrm{MEA}}^{2}\right) \mathrm{m}_{\mathrm{MEA}}\left(1-\mathrm{m}_{\mathrm{MEA}}\right) \sqrt{1-\varphi_{\mathrm{MEA}}^{2}} \\
\varphi_{\mathrm{MEA}}=\frac{\mathrm{m}_{\mathrm{MEA}} \mathrm{M}_{\mathrm{MEA}} / \rho_{\mathrm{MEA}}}{\mathrm{m}_{\mathrm{MEA}} \mathrm{M}_{\mathrm{MEA}} / \rho_{\mathrm{MEA}}+\left(1-\mathrm{m}_{\mathrm{H}_{2} \mathrm{O}}\right) \mathrm{M}_{\mathrm{H}_{2} \mathrm{O}} / \rho_{\mathrm{H}_{2} \mathrm{O}}} \\
\ln \left(\mathrm{H}_{\mathrm{N}_{2} \mathrm{O}}^{\mathrm{MEA}}\right)=3.9451-\frac{589.9365}{\mathrm{~T}-99.0406}
\end{gathered}
$$

where $\Delta \mathrm{H}_{\mathrm{N}_{2} \mathrm{O}}^{\text {loded }}$ and $\Delta \mathrm{H}_{\mathrm{N}_{2} \mathrm{O}}^{\text {unloaded }}$ were the apparent Henry's constant deviation in aqueous MEA solution with and without $\mathrm{CO}_{2}, \mathrm{kPa} \cdot \mathrm{m}^{3} \cdot \mathrm{mol}^{-1} \cdot \mathrm{H}_{\mathrm{N}_{2} \mathrm{O}}^{\text {unloded }}$ was Henry's constant of $\mathrm{N}_{2} \mathrm{O}$ in aqueous MEA solution without $\mathrm{CO}_{2}, \mathrm{kPa} \cdot \mathrm{m}^{3} \cdot \mathrm{mol}^{-1} \cdot \mathrm{m}_{\mathrm{MEA}}$ and $\mathrm{m}_{\mathrm{H}_{2} \mathrm{O}}$ were the mole fraction of MEA and $\mathrm{H}_{2} \mathrm{O}$ in aqueous MEA solution, respectively. $\alpha$ was $\mathrm{CO}_{2}$ loading in aqueous MEA solution, $\mathrm{mol}_{\mathrm{CO}_{2}} / \mathrm{mol}_{\mathrm{MEA}} \cdot \varphi_{\mathrm{MEA}}$ and $\varphi_{\mathrm{H}_{2} \mathrm{O}}$ were the volume fraction of MEA and $\mathrm{H}_{2} \mathrm{O}$, respectively. $\mathrm{H}_{\mathrm{N}_{2} \mathrm{O}}^{\mathrm{MEA}}$ was Henry's constant of $\mathrm{N}_{2} \mathrm{O}$ in MEA, $\mathrm{kPa} \cdot \mathrm{m}^{3} \cdot \mathrm{mol}^{-1} \cdot \mathrm{M}_{\mathrm{MEA}}$ and $\mathrm{M}_{\mathrm{H}_{2} \mathrm{O}}$ were the molecular mass of MEA and 
$1 \mathrm{H}_{2} \mathrm{O}$, respectively, $\mathrm{kg} \cdot \mathrm{mol}^{-1} \cdot \rho_{\mathrm{MEA}}$ and $\rho_{\mathrm{H}_{2} \mathrm{O}}$ were the density of MEA and $\mathrm{H}_{2} \mathrm{O}$,

2 respectively, $\mathrm{kg} \cdot \mathrm{m}^{-3}$. The reaction between $\mathrm{MEA}$ and $\mathrm{CO}_{2}$ was considered as a fast

3 irreversible process. In this case, $\mathrm{CO}_{2}$ concentration in the bulk liquid phase was

4 assumed zero, given that the liquid side mass transfer coefficient was significantly

5 lower than the apparent reaction rate as analyzed by Kasturi and Stepanek. ${ }^{43}$

\section{$6 \quad$ 3.3. Determination of Bubble Volume}

7 Figure 2(b) shows the bubble cross-section model. Its volume and surface area

$8 \quad$ were expressed by the following. ${ }^{14,44}$

9

$$
\begin{aligned}
\mathrm{V}_{\mathrm{CO}_{2}} & =\left[(\pi-4) \mathrm{I}^{2}+\left(\mathrm{d}_{\mathrm{H}}-2 \delta\right)^{2}\right]\left(\mathrm{L}_{\mathrm{B}}-\mathrm{d}_{\mathrm{H}}\right)+\frac{4}{3} \pi\left(0.5 \mathrm{~d}_{\mathrm{H}}-\delta\right)^{3} \\
\mathrm{~A}_{\mathrm{S}} & =\left[2 \pi \mathrm{I}+4\left(\mathrm{~d}_{\mathrm{H}}-2 \delta-2 \mathrm{I}\right)\right]\left(\mathrm{L}_{\mathrm{B}}-\mathrm{d}_{\mathrm{H}}\right)+4 \pi\left(0.5 \mathrm{~d}_{\mathrm{H}}-\delta\right)^{2}
\end{aligned}
$$

where $I$ was the radius of the quadrant at the corner and obtained from the captured images, m. $d_{H}$ and $\mathrm{L}_{\mathrm{B}}$ were the hydraulic diameter and the length of Taylor bubble, respectively, $\mathrm{m} . \delta$ denoted the liquid film thickness near the channel wall center and estimated by the correlation from Aussillous and Quéré. ${ }^{45}$

$$
\begin{gathered}
\frac{\delta}{\mathrm{D}_{\mathrm{H}}}=\frac{0.67 \mathrm{Ca}^{2 / 3}}{1+3.35 \mathrm{Ca}^{2 / 3}} \\
\mathrm{Ca}=\frac{\mu_{\mathrm{L}} \mathrm{U}_{\mathrm{B}}}{\gamma_{\mathrm{TP}}}
\end{gathered}
$$

where $C a$ was capillary number. $\mu_{\mathrm{L}}$ was the liquid phase viscosity, Pa.s. $\gamma_{\mathrm{TP}}$ was the gas-liquid two-phase interfacial tension and expressed by the correlation proposed by Vázquez et al. ${ }^{46}$

$$
\gamma_{\mathrm{TP}}=\gamma_{\mathrm{H}_{2} \mathrm{O}}-\left(\gamma_{\mathrm{H}_{2} \mathrm{O}}-\gamma_{\mathrm{MEA}}\right)\left(1+\frac{0.6272 \mathrm{~m}_{\mathrm{H}_{2} \mathrm{O}}}{1-0.9465 \mathrm{~m}_{\mathrm{H}_{2} \mathrm{O}}}\right) \mathrm{m}_{\mathrm{MEA}}
$$


1 where $\gamma_{\mathrm{H}_{2} \mathrm{O}}$ and $\gamma_{\mathrm{MEA}}$ were the surface tension of pure water and MEA, respectively,

$2 \mathrm{~N} / \mathrm{m}\left(25^{\circ} \mathrm{C}, \gamma_{\mathrm{H}_{2} \mathrm{O}}=0.07201, \gamma_{\mathrm{MEA}}=0.04895\right)$. The solution viscosity of the aqueous

3 MEA solution without $\mathrm{CO}_{2}$ was calculated by the correlation by Hartono et al. ${ }^{41}$

4

$$
\begin{aligned}
\ln \left(\mu^{\text {unloaded }}\right)= & \mathrm{m}_{\mathrm{MEA}}\left(8.36-4.664 \times 10^{-2} \mathrm{t}+1.6 \times 10^{-4} \mathrm{t}^{2}-4.14 \mathrm{~m}_{\mathrm{MEA}}\right) \mathrm{m}_{\mathrm{H}_{2} \mathrm{O}} \\
& +\mathrm{m}_{\mathrm{H}_{2} \mathrm{O}} \ln \left(\mu_{\mathrm{H}_{2} \mathrm{O}}\right)+\mathrm{m}_{\mathrm{MEA}} \ln \left(\mu_{\mathrm{MEA}}\right)
\end{aligned}
$$

5 where $\mu^{\text {unloaded }}$ was the viscosity of aqueous MEA solution without $\mathrm{CO}_{2}$ absorption,

$6 \mathrm{~Pa} \cdot \mathrm{s} . \mu_{\mathrm{MEA}}$ and $\mu_{\mathrm{H}_{2} \mathrm{O}}$ were the viscosity of pure MEA and water, $\mathrm{Pa} \cdot \mathrm{s}\left(25^{\circ} \mathrm{C}\right.$,

$\left.7 \quad \mu_{\mathrm{H}_{2} \mathrm{O}}=8.937 \times 10^{-4} ; \mu_{\mathrm{MEA}}=1.79 \times 10^{-2}\right) . t$ was the solution temperature, ${ }^{\circ} \mathrm{C}$. The

8 concentration of MEA was very low, and the solution viscosity with $\mathrm{CO}_{2}$ was replaced

9 by $\mu^{\text {unloaded }}$. So, the film thickness was calculated from Eqs. (28)-(31).

10 In this work, $\mathrm{L}_{\mathrm{CO}_{2}}$ and $\mathrm{U}_{\mathrm{B}}$ were calculated along the microchannel by 1000

11 continuously captured images. The bubble volume was calculated by Eq. (26) along

12 the channel position, and then $\mathrm{dV}_{\mathrm{B}} / \mathrm{dX}$. The liquid phase volume within the unit cell 13 was determined from the formation frequency of the liquid slug. The gas phase 14 pressure was measured by the pressure sensor. The equilibrium solubility along the 15 channel position was calculated by Eqs. (16)-(25). Finally, $E$ and $k_{L} a$ were calculated 16 by Eqs. (12) \& (15), respectively.

17

18

19

20

21

\section{RESULTS AND DISCUSSION}

\subsection{Length and Velocity of Gas Bubbles}

The stable gas-liquid Taylor flow was formed at the T-junction and tracked along the serpentine microchannel. Figure 3 illustrates the evolution of $\mathrm{CO}_{2}$ bubbles with and without chemical reaction along the microchannel. More experimental data are 
1 shown in Figure S1 of Supporting Information (SI). As bubbles moved downstream,

2 their length gradually decreased and finally leveled off, indicating $\mathrm{CO}_{2}$ absorption

3 reached equilibrium, which was similar to $\mathrm{CO}_{2}-\mathrm{H}_{2} \mathrm{O}$ system. ${ }^{14}$

4

5
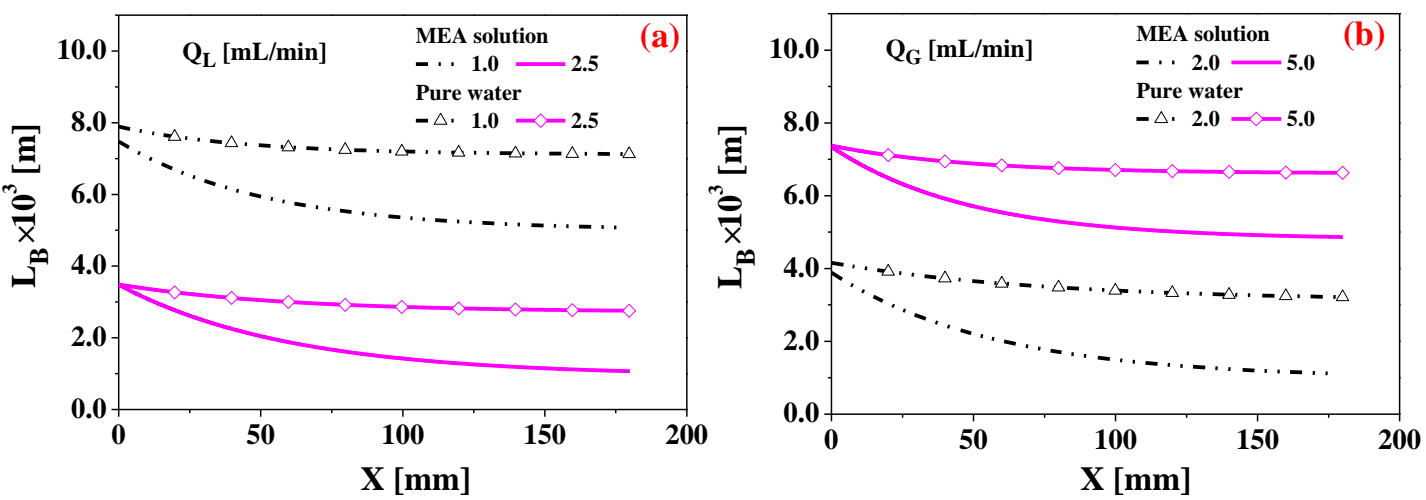

Figure 3. The evolution of Taylor bubble length along the serpentine microchannel at $25{ }^{\circ} \mathrm{C}, 1.0 \mathrm{~atm}$ and $W_{\mathrm{MEA}}=1 \mathrm{wt} \%$ for (a) $\mathrm{Q}_{\mathrm{G}}=5.5 \mathrm{~mL} / \mathrm{min}$, and (b) $\mathrm{Q}_{\mathrm{L}}=1 \mathrm{~mL} / \mathrm{min}$. Initial bubble length at the T-junction $(X=0)$ decreased with an increase in the liquid flow rate (1.0-2.5 mL/min) (Figure 3(a) \& Figure $\mathrm{S} 1(\mathrm{a})$ ), or with reducing gas flow rates (Figure 3(b) \& Figure $\mathrm{S} 1(\mathrm{~b})$ ). Compared to $\mathrm{CO}_{2}-\mathrm{H}_{2} \mathrm{O}$ system, the initial bubble length appeared reduced considerably, where the reducing extent decreased with increasing liquid flow rate for a given gas flow rate. These phenomena were the results of the combination of the physical properties of the solution and chemical reaction. The increase in MEA content (0-1 wt $\%)$ in solution led to the increasing of the liquid viscosity and the decreasing of gas-liquid interfacial tension, as shown in Table 2. Because the variation of the interfacial tension was very small (72.01-71.18 $\mathrm{N} \cdot \mathrm{m}$ ), the effects of the gas-liquid interfacial tension on the initial bubble length were insignificant. ${ }^{47}$ Previous studies have shown the initial bubble length decreased with the increasing of the liquid phase viscosity. ${ }^{10,48}$ In addition, the mass transfer with chemical reaction during the formation of Taylor bubble further decreased the initial 
1 bubble length. ${ }^{49}$

Table 2. Liquid phase viscosity and gas-liquid interfacial tension

\begin{tabular}{ccccccc}
\hline $\boldsymbol{W}_{\mathrm{MEA}} / \mathrm{wt} \%$ & 0 & 1.0 & 1.5 & 2.0 & 2.5 & 3.0 \\
\hline $\boldsymbol{\mu} \times 10^{-3 /} \mathrm{Pa} \cdot \mathrm{s}$ & 0.894 & 0.921 & 0.936 & 0.950 & 0.965 & 0.980 \\
$\boldsymbol{\gamma} \times 10^{-3} / \mathrm{N} \cdot \mathrm{m}$ & 72.01 & 71.18 & 70.79 & 70.42 & 70.06 & 69.71 \\
\hline
\end{tabular}

During Taylor bubble flowing along the microchannel, the shrinkage of $\mathrm{CO}_{2}$ bubble was accelerated by chemical reaction in comparison to $\mathrm{CO}_{2}-\mathrm{H}_{2} \mathrm{O}$ system (Figure $3 \&$ Figure $\mathrm{S} 1)$. In the first $60 \mathrm{~mm}(\mathrm{X} \leq 60 \mathrm{~mm})$ section, which was named as the rapid shrinkage stage, Taylor bubble shrank rapidly where approximate $70 \%$ of total length reduction $\left(\Delta L_{B}\right)$ was observed. In the second $60 \mathrm{~mm}(60<\mathrm{X} \leq 120 \mathrm{~mm})$ section, the reduction of $\Delta L_{B}$ approached $25 \%$, which was regarded as the moderate shrinkage stage. In the third $60 \mathrm{~mm}(120<\mathrm{X} \leq 180 \mathrm{~mm})$ section, the bubble length kept almost constant where only $5 \%$ of $\Delta L_{B}$ was completed, suggesting an equilibrium shrinkage stage. This originated from the interplay of three competitive factors during the evolution of the bubbles, i.e., $\mathrm{CO}_{2}$ dissolution, chemical reaction and gas-liquid two-phase pressure drop.

As found in our previous work, ${ }^{14}$ the evolution of the bubbles along the microchannel was determined by $\mathrm{CO}_{2}$ dissolution and pressure drop. The existence of chemical reaction in the present work could intensify the shrinkage of Taylor bubble, which led to shorter bubble lengths and $70 \%$ of $\Delta L_{B}$ at the rapid shrinkage stage, as shown in Figure 4. With the bubble flowing downstream, MEA was gradually consumed, the reaction rate was weakened, and the decrease in bubble length reduced 
1 and finally leveled off.

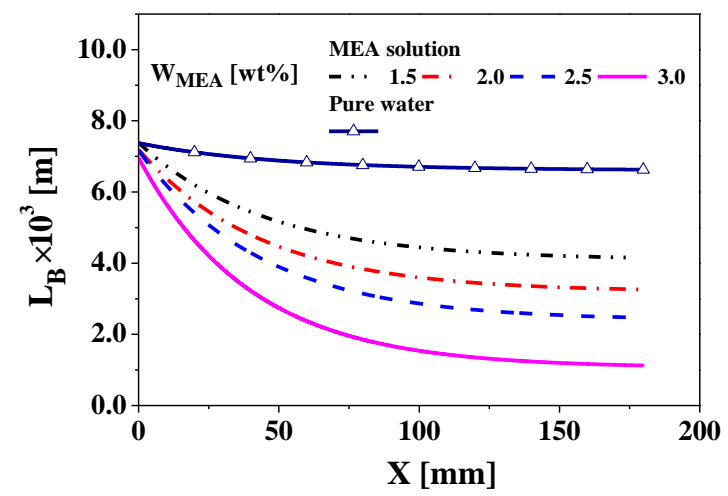

Figure 4. The effects of MEA content on the bubble length of along the serpentine microchannel for $\mathrm{Q}_{\mathrm{G}}=5 \mathrm{~mL} / \mathrm{min}$ and $\mathrm{Q}_{\mathrm{L}}=1 \mathrm{~mL} / \mathrm{min}$.

Figure 5 \& Figure S2 depict the evolution of Taylor bubble velocity accompanied with and without chemical reaction along the serpentine microchannel by varying gas (or liquid) flow rate. It was also observed that the bubble velocity decreased drastically for aqueous MEA solution, compared to the $\mathrm{CO}_{2}-\mathrm{H}_{2} \mathrm{O}$ system. The reduction in Taylor bubble velocity at three stages (the rapid, moderate and equilibrium shrinkage stages) were found to be $75 \%, 19 \%$ and $6 \%$ for a given gas flow rate, respectively. Figure 5(a) \& Figure S2(a) also present the existence of a critical point during the evolution of the bubble velocity for $\mathrm{CO}_{2}$-MEA system. It was attributed to the competition of two kinds of modes when increasing in liquid flow rate. One was the increase in the bubble velocity (the increasing mode), while the other one was the increase in the absorption rate that reduced the bubble velocity (the decreasing mode). As could be seen from Figure 5(a) \& Figure S2(a), the bubble velocity increased with the liquid flow rate before the critical point, indicating that the increasing mode was dominant. After the critical point, the decreasing mode began to dominate. Figure 5(b) \& Figure S2(b) shows Taylor bubble velocity increased with 
1 increasing gas flow rate for a given liquid flow rate. Obviously, the gas flow rate

2 dominated over the increase in bubble velocity. The reductions in bubble velocity at

3 three stages were $72 \%, 22 \%$ and $6 \%$ for a given liquid flow rate, respectively. The

4 effects of MEA content on bubble velocity are shown in Figure 6. The reduction in

5 bubble velocity in three stages was found to be $83 \%, 14 \%$ and $3 \%$, respectively. The

6 changes of in bubble velocity were similar to that of $\mathrm{CO}_{2}$ bubble length as displayed

7 in Figure 4. The results allowed us to identify key parameters such as flow rate and

8 absorption rate for understanding and quantifying the dynamic evolution of

9 mass transfer.
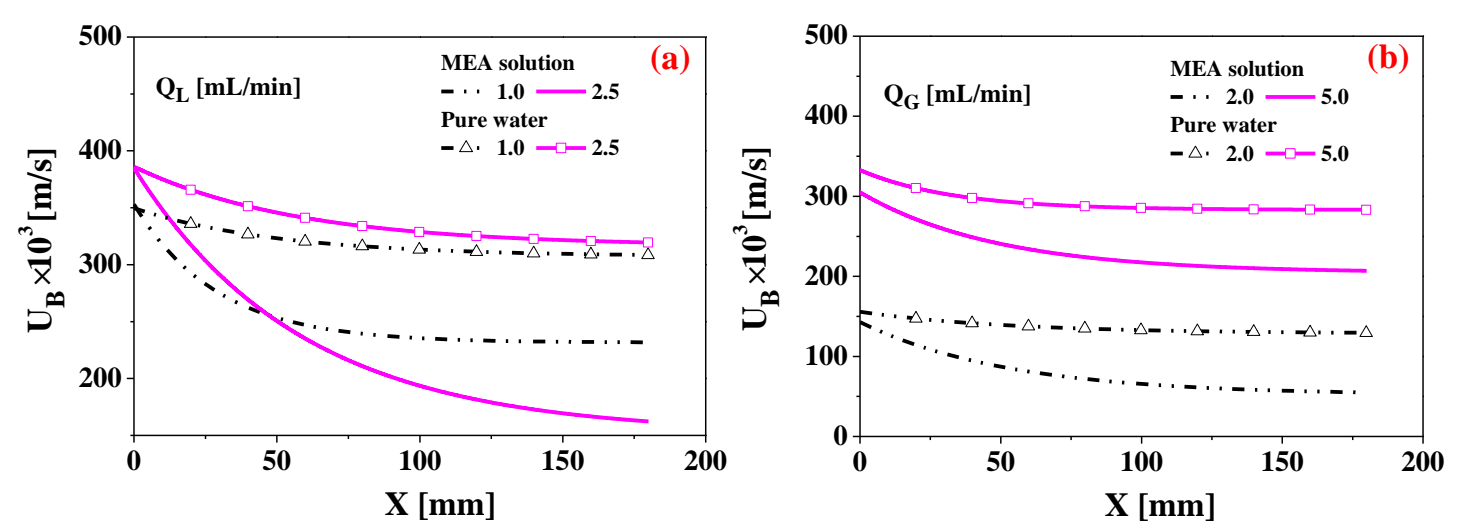

Figure 5. The evolution of Taylor bubble velocity along the serpentine microchannel at $25{ }^{\circ} \mathrm{C}, 1.0 \mathrm{~atm}$ and $\mathrm{W}_{\mathrm{MEA}}=1 \mathrm{wt} \%$ for (a) $\mathrm{Q}_{\mathrm{G}}=5.5 \mathrm{~mL} / \mathrm{min}$, and (b) $\mathrm{Q}_{\mathrm{L}}=1 \mathrm{~mL} / \mathrm{min}$.

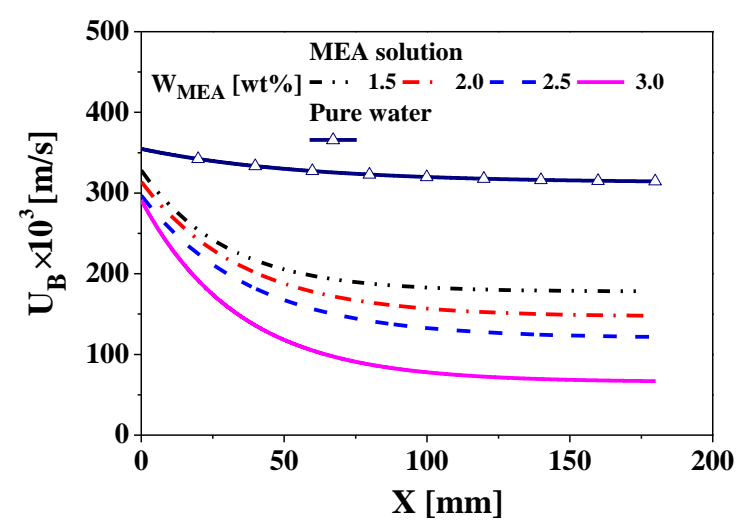

14 Figure 6. The effects of MEA content on the velocity of Taylor bubble along the serpentine microchannel for $\mathrm{Q}_{\mathrm{G}}=5 \mathrm{~mL} / \mathrm{min}$ and $\mathrm{Q}_{\mathrm{L}}=1 \mathrm{~mL} / \mathrm{min}$. 


\subsection{Gas-Liquid Mass Transfer Coupled with Chemical Reaction}

$k_{L} a, k_{L}$ and $a$ are generally regarded as key parameters to characterize the gas-liquid mass transfer. Figure $7 \&$ Figure S3 show the comparison of measured $k_{L} a$ along the serpentine microchannel for $\mathrm{CO}_{2}-\mathrm{H}_{2} \mathrm{O}$ and $\mathrm{CO}_{2}$-MEA systems. Compared to $\mathrm{CO}_{2}-\mathrm{H}_{2} \mathrm{O}$ system, $k_{L} a$ increased considerably due to the chemical reaction. For a given gas (or liquid) flow rate, $k_{L} a$ increased with the increasing of liquid (or gas)

flow rate. The effects of the liquid flow rate were more significant, which could be also attributed to the role of chemical reaction. Moreover, $k_{L} a$ in a unit cell decreased along the microchannel for both $\mathrm{CO}_{2}-\mathrm{H}_{2} \mathrm{O}$ and $\mathrm{CO}_{2}$-MEA system, where the latter exhibited more dramatic decrease.
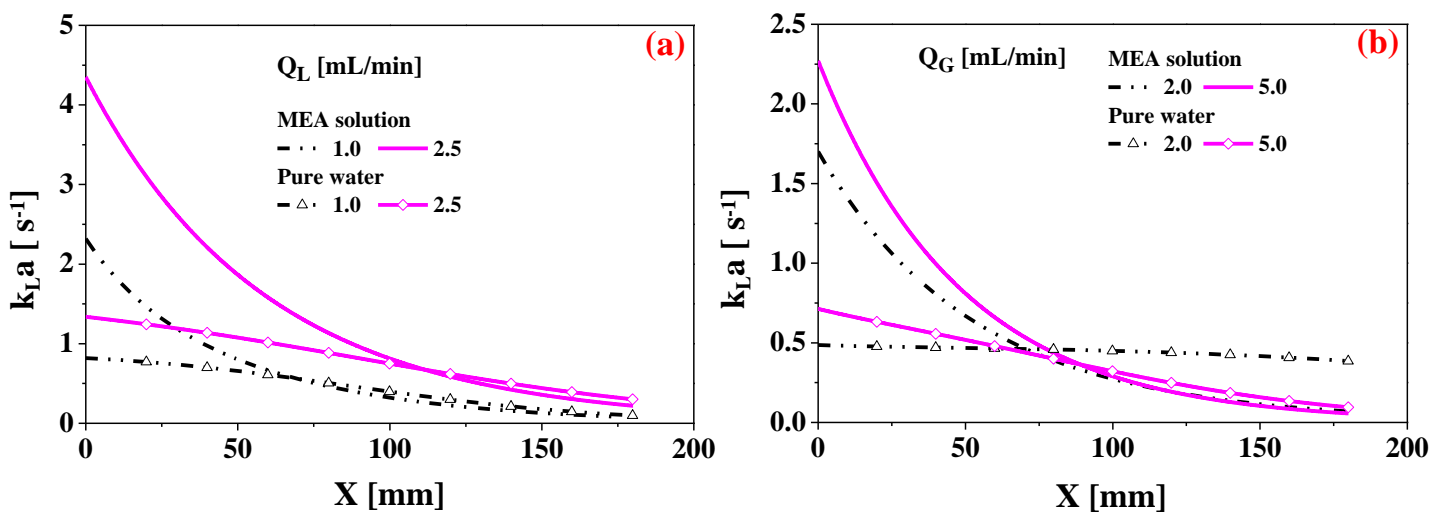

Figure 7. The effects of the gas or liquid flow rate on $k_{L} a$ in a unit cell along the serpentine microchannel at $25{ }^{\circ} \mathrm{C}, 1.0$ atm and $\mathrm{W}_{\mathrm{MEA}}=1 \mathrm{wt} \%$ for (a) $\mathrm{Q}_{\mathrm{G}}=5.5 \mathrm{~mL} / \mathrm{min}$, and (b) $\mathrm{Q}_{\mathrm{L}}=1 \mathrm{~mL} / \mathrm{min}$.

In the rapid shrinkage stage $(\mathrm{X} \leq 60 \mathrm{~mm})$, approximate $78 \%$ reduction in $k_{L} a\left(\Delta\left(k_{L} a\right)\right)$ was obtained, where $\Delta\left(k_{L} a\right)$ denoted the difference between the initial $(\mathrm{X}=0 \mathrm{~mm})$ and the end $(X=180 \mathrm{~mm})$ of the volumetric liquid phase mass transfer coefficient in a unit cell. In the moderate shrinkage stage $(60<\mathrm{X} \leq 120 \mathrm{~mm}), \Delta\left(k_{L} a\right)$ approached $17 \%$. In the equilibrium shrinkage stage $(120<\mathrm{X} \leq 180 \mathrm{~mm})$, the value of $k_{L} a$ decreased until 
1 becoming almost constant, where only 5\% occurred. The effects of MEA content on

$2 k_{L} a$ are depicted in Figure 8. $k_{L} a$ increased with increasing MEA content due to the

3 reaction enhancement. About $78 \%$ and $17 \%$ reduction in $k_{L} a$ were obtained in the first

4 and second stages, respectively. The significantly higher reduction in the first stage

5 demonstrated the kinetic effect of the fast reaction.

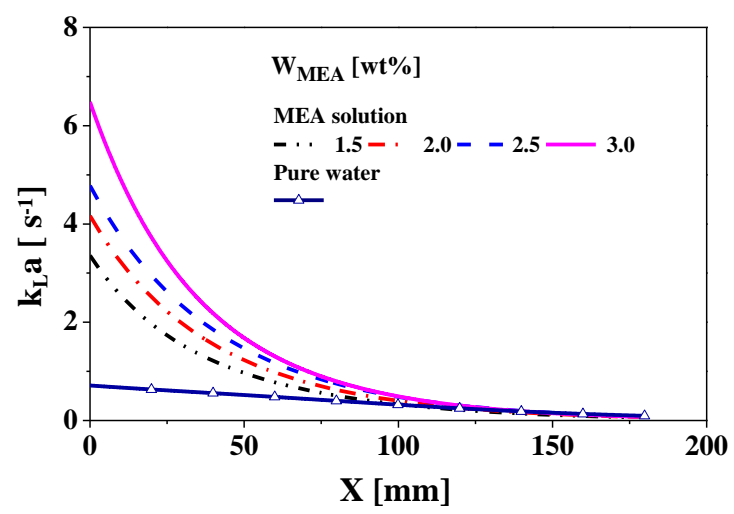

Figure 8. The effects of MEA content on $k_{L} a$ in a unit cell along the serpentine microchannel at $25^{\circ} \mathrm{C}$ and 1.0 atm for $\mathrm{Q}_{\mathrm{G}}=5 \mathrm{~mL} / \mathrm{min}$ and $\mathrm{Q}_{\mathrm{L}}=1 \mathrm{~mL} / \mathrm{min}$.

In order to further elucidate the gas-liquid mass transfer performance for $\mathrm{CO}_{2}-\mathrm{MEA}$ system, $k_{L}$ and $a$ were separately analyzed. Figure $9 \&$ Figure S4 compares the evolution of $k_{L}$ along the microchannel for both $\mathrm{CO}_{2}-\mathrm{MEA}$ and $\mathrm{CO}_{2}-\mathrm{H}_{2} \mathrm{O}$ systems. The decrease of $k_{L}$ in $\mathrm{CO}_{2}$-MEA system was more dramatic than that in $\mathrm{CO}_{2}-\mathrm{H}_{2} \mathrm{O}$ system due to the intensification of chemical reaction, which was found to be $68 \%, 24 \%$ and $8 \%$ in three stages, respectively.

For a given gas flow rate, $k_{L}$ increased with the increasing liquid phase flow rate, but decreased sharply as Taylor bubbles moved downstream along the microchannel for $\mathrm{CO}_{2}$-MEA system (Figure 9(a) \& Figure $\mathrm{S} 4(\mathrm{a})$ ), which was determined synergistically by the leakage flow in the liquid film and the circulation in the liquid slug. Taylor bubble velocity decreased sharply for $\mathrm{CO}_{2}$-MEA system (Figure 5(a) \& 
1 Figure S2(a)), which led to the significant decrease of the circulation and then $k_{L}$, and

2 such effects were weakened gradually along the microchannel. In addition, increasing

3 the viscosity of aqueous MEA solution (Table 2) could also decrease $k_{L}$ by reducing

4 the diffusion coefficient and the circulation. However, the substantial decrease of the

5 bubble length (Figure 3(a) \& Figure S1(a)) caused the reduction of the liquid film

6 length between the bubble and the channel wall, where the leakage flow in the film

7 was enhanced and in favor of increasing $k_{L}$. With the consumption of MEA in liquid

8 phase, the effect of chemical reaction was gradually weakened, where $k_{L}$ approached

9 to $\mathrm{CO}_{2}-\mathrm{H}_{2} \mathrm{O}$ system. Finally, both positive and negative effects on $k_{L}$ determined the 10 results of Figure 9(a) \& Figure S4(a).

11
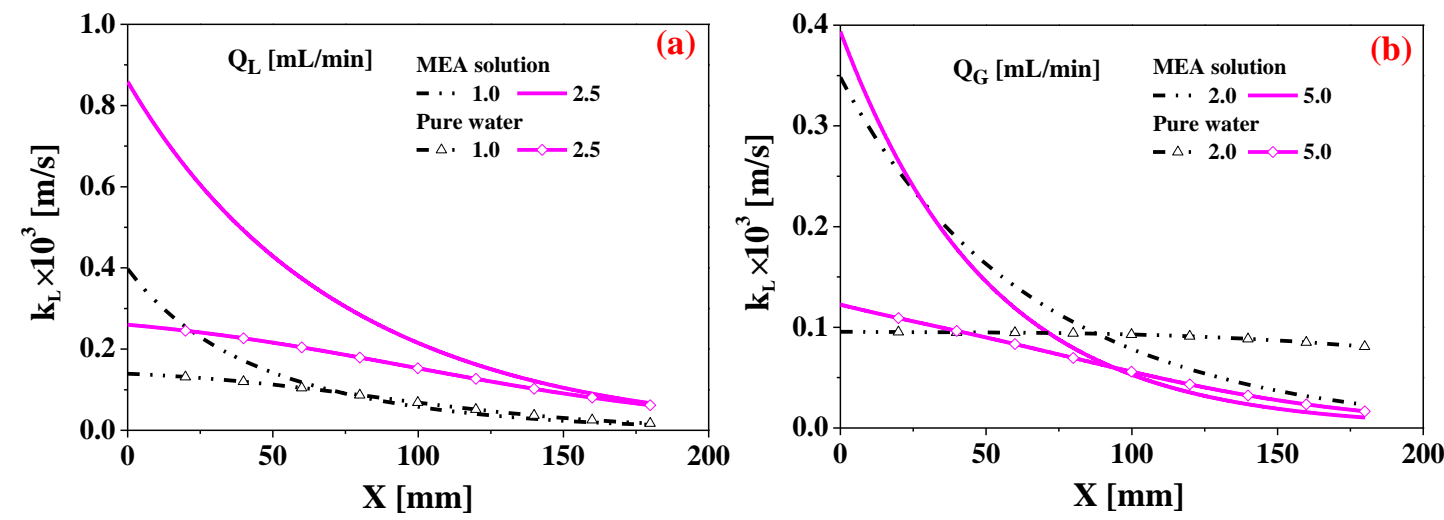

Figure 9. The evolution of $k_{L}$ in a unit cell along the serpentine microchannel at $25{ }^{\circ} \mathrm{C}$, 1.0 atm and $\mathrm{W}_{\mathrm{MEA}}=1 \mathrm{wt} \%$ for (a) $\mathrm{Q}_{\mathrm{G}}=5.5 \mathrm{~mL} / \mathrm{min}$, and (b) $\mathrm{Q}_{\mathrm{L}}=1 \mathrm{~mL} / \mathrm{min}$.

For a given liquid flow rate, there was also a critical position $(\mathrm{X} \approx 25 \mathrm{~mm})$ for $k_{L}$ along the microchannel (Figure 9(b) \& Figure S4(b)), where the reductions in $k_{L}$ at three stages were $67 \%, 24 \%$ and $9 \%$, respectively. When $\mathrm{X}<25 \mathrm{~mm}, k_{L}$ increased with the increase in the gas phase flow rate, and decreased as $X>25 \mathrm{~mm}$. This was similar to the conclusion of our previous work. ${ }^{14}$ However, the point moved forward compared to $\mathrm{CO}_{2}-\mathrm{H}_{2} \mathrm{O}$ system. As we all known, $\mathrm{CO}_{2}$ absorption capacity was 
1 constant for a given initial MEA content, the larger the bubble length or the gas flow

2 rate was, the more decreasing extent of free MEA molecule and $\mathrm{CO}_{2}$ absorption,

3 which weakened dramatically the intensification of chemical reaction on $k_{L}$ as

4 absorption proceeded. Simultaneously, the liquid slug velocity decreased due to $\mathrm{CO}_{2}$

5 absorption, which also reduced the circulation in the liquid slug. On the other hand,

6 the increasing gas flow rate and the decreasing bubble length were in favor of $k_{L}$ by

7 enhancing the circulation and the leakage flow, respectively. Compared to $\mathrm{CO}_{2}-\mathrm{H}_{2} \mathrm{O}$

8 system, both the negative and positive effects on $k_{L}$ were enlarged due to chemical

9 reaction, and finally the critical point occurred in advance for $\mathrm{CO}_{2}-\mathrm{MEA}$ system.

10
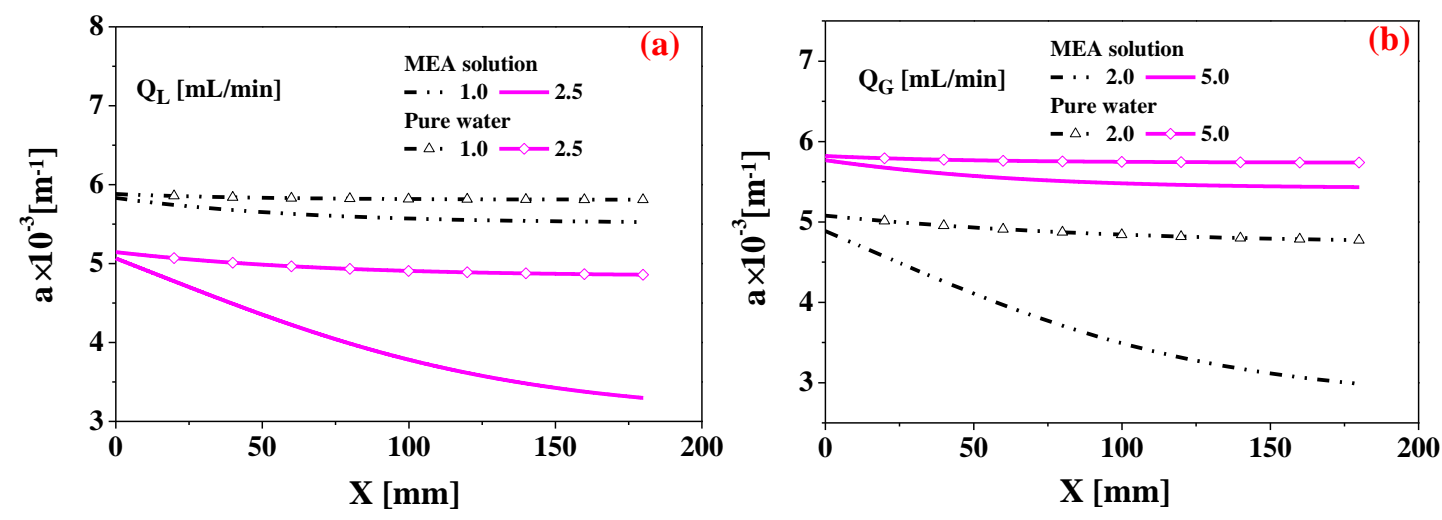

Figure 10. The evolution of $a$ in a unit cell along the serpentine microchannel at 25

${ }^{\circ} \mathrm{C}, 1.0 \mathrm{~atm}$ and $\mathrm{W}_{\mathrm{MEA}}=1 \mathrm{wt} \%$ for (a) $\mathrm{Q}_{\mathrm{G}}=5.5 \mathrm{~mL} / \mathrm{min}$, and (b) $\mathrm{Q}_{\mathrm{L}}=1 \mathrm{~mL} / \mathrm{min}$.

Figure $10 \&$ Figure S5 shows the evolution of $a$ in a unit cell along the serpentine microchannel. The reduction of $a$ in three stages were $57 \%, 30 \%$ and $13 \%$, respectively, which were smaller than the variation of $k_{L}$. Compared to $\mathrm{CO}_{2}-\mathrm{H}_{2} \mathrm{O}$ system under the identical conditions, the decrease of $a$ was accelerated as Taylor bubbles moved downstream along the microchannel, especially for the initial shorter bubble length which approached to spherical (i.e., bubble sphericity $\Phi$ ), as shown in Figure 11\& Figure S6. The effects of MEA content on gas-liquid mass transfer 
1 performance, in terms of $k_{L}, a$ and $\Phi$, are depicted in Figure 12. The reductions in $a$

2 and $k_{L}$ in three stages were $60 \%, 30 \%$ and $10 \%$, respectively. It was observed $k_{L}$ and

3 its reducing degree increased with increasing MEA content. On the one hand, the

4 decrease in the length of the bubble and the liquid film could lead to the increase of $k_{L}$.

5 On the other hand, both the decrease of the bubble velocity and the increase of the

6 liquid phase viscosity resulted in the decrease of $k_{L}$ by weakening the circulation.

7 Finally, the positive and negative factors from MEA content together determined the

8 dynamic changes of $k_{L}$ (Figure 12(a)). As generally known, the increase of MEA

9 content resulted in increasing $\mathrm{CO}_{2}$ absorption rate and capacity in aqueous MEA

10 solution, which further accelerated the decrease of bubble length and the increase of

11 its $\Phi$, and led to the decrease of $a$ (Figure 12(b) \& (c)).
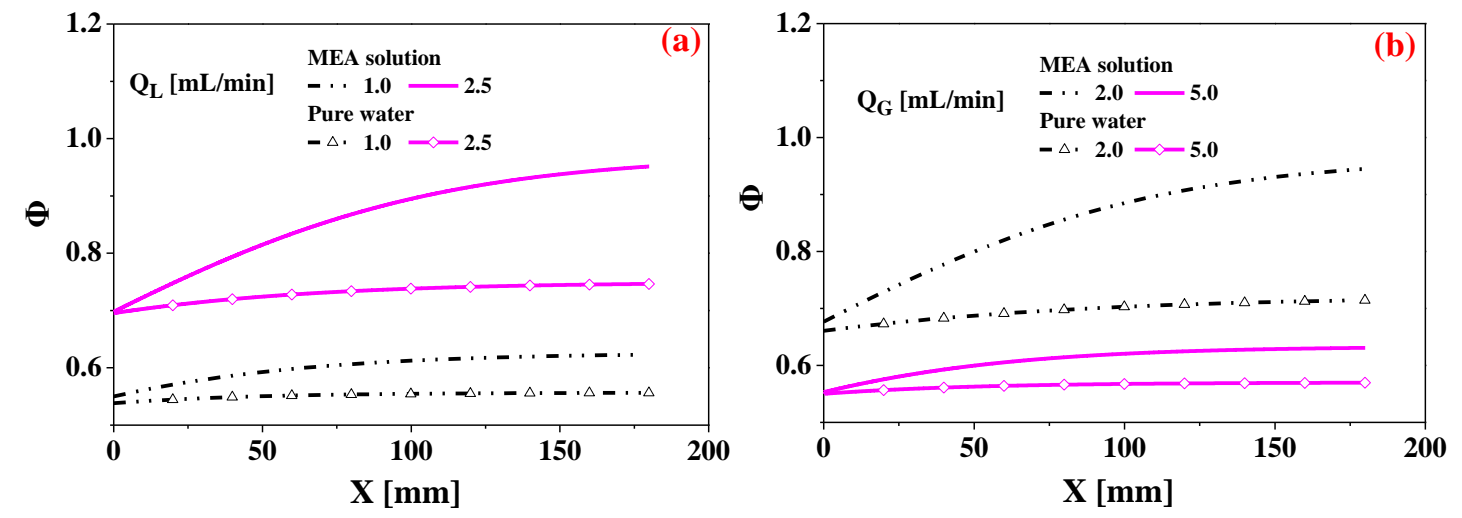

13 Figure 11. The evolution of the sphericity $(\Phi)$ along the serpentine microchannel, at 14 $25{ }^{\circ} \mathrm{C}, 1.0$ atm and $\mathrm{W}_{\mathrm{MEA}}=1 \mathrm{wt} \%$ for (a) $\mathrm{Q}_{\mathrm{G}}=5.5 \mathrm{~mL} / \mathrm{min}$, and (b) $\mathrm{Q}_{\mathrm{L}}=1 \mathrm{~mL} / \mathrm{min}$.
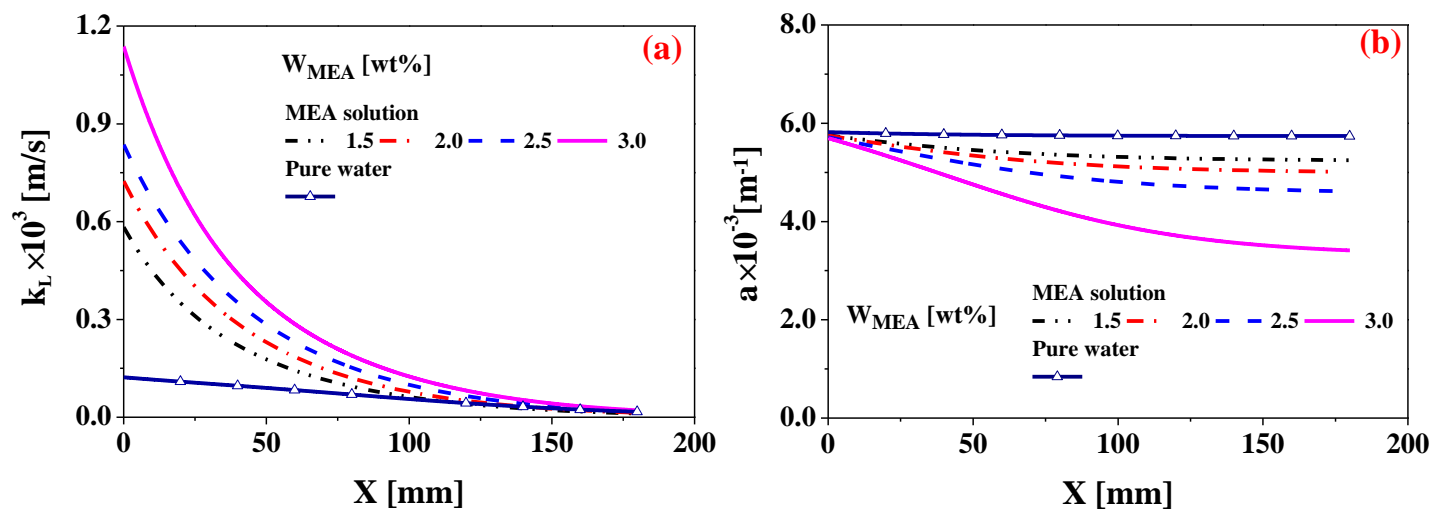


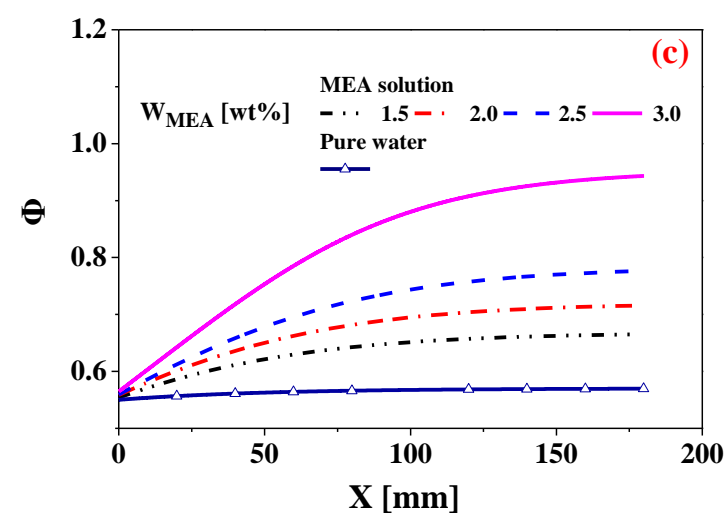

Figure 12. The effects of the MEA content on $a(\mathrm{a}), k_{L}(\mathrm{~b})$ and $\Phi$ (c) along the serpentine microchannel at $25{ }^{\circ} \mathrm{C}, 1.0$ atm for $\mathrm{Q}_{\mathrm{G}}=5 \mathrm{~mL} / \mathrm{min}$ and $\mathrm{Q}_{\mathrm{L}}=1 \mathrm{~mL} / \mathrm{min}$.

\subsection{Dynamic Changes of the Enhancement Factor}

It was reasonably expected that gas-liquid two-phase mass transfer performance could be enhanced by chemical reaction for $\mathrm{CO}_{2}$-MEA system. To quantitatively characterize the process, $E$ was adopted to represent the ratio of mass transfer between with and without chemical reaction. However, the local dynamic conditions are generally difficult to measure directly in any reactor because the mass transfer never stops before reaching the absorption equilibrium, representing the dynamic process of gas-liquid two-phase flow. Figure 13(a) demonstrates the dynamic changes of $E_{\text {exp }}$ along the microchannel at four MEA contents, where the experimental enhancement factor $\left(E_{\text {exp }}\right)$ of $\mathrm{CO}_{2}$-MEA system was calculated from the following equation by taking into account of both $\mathrm{k}_{\mathrm{L}}^{0}$ and $k_{L}$.

$$
\mathrm{E}_{\text {exp }}=\frac{\mathrm{k}_{\mathrm{L}}\left(\mathrm{C}_{\mathrm{Ai}}-\mathrm{C}_{\mathrm{CO}_{2}}^{\mathrm{L}}\right)}{\mathrm{k}_{\mathrm{L}}^{0} \mathrm{C}_{\mathrm{CO}_{2}}^{*, \mathrm{~L}}}
$$

where $\mathrm{k}_{\mathrm{L}}^{0}$ denotes the physical mass transfer coefficient for identical operating conditions at the entrance of microchannel for $\mathrm{CO}_{2}-\mathrm{H}_{2} \mathrm{O}$ and $\mathrm{CO}_{2}-\mathrm{MEA}$ system. That is, the maximum physical mass transfer coefficient is chosen for a given operating 
condition.

For a given gas and liquid flow rate, $E$ increased with the increasing MEA content and also decreased gradually as Taylor bubbles moved downstream along the microchannel. The chemical reaction rate was proportional to MEA content. Furthermore, the viscosity of the solution increased with the increase of MEA content, which could weaken the influence of chemical reaction. As Taylor bubbles moved beyond the critical value, $E$ tended to be stable and close to one, indicating that the intensification of the chemical reaction was weakened until to be ignored. This suggested the microchannel length could be optimized based on the above critical position for the design of gas-liquid two-phase low pressure drop microchannel reactor.

The enhancement factor $\left(E_{\text {exp }}\right)$ of $\mathrm{CO}_{2}$-MEA system agreed well with the calculated enhancement factor $\left(E_{c a l}\right)$ from Eq. 12, which indicated the validity of the model, as shown in Figure 13(b). Hikita et al. ${ }^{50}$ investigated the kinetics of the reaction of $\mathrm{CO}_{2}$ with MEA for MEA concentration in the range of $0.0152-0.177 \mathrm{~mol} / \mathrm{L}$ at temperatures ranging from $5.6{ }^{\circ} \mathrm{C}$ to $35.4{ }^{\circ} \mathrm{C}$, and found the reaction to be an irreversible second order reaction. In the present work, the initial MEA concentration was varied in the range of $0.163-0.490 \mathrm{~mol} / \mathrm{L}$, so the reaction rate can be expressed reasonably by the second-order model. Furthermore, Santiago and Farina ${ }^{51}$ demonstrated that the accuracy of the prediction of this model was $3 \%$ for fast second order and irreversible reactions with $\mathrm{Ha}>3$. In the present work, Ha values (Figure 13(c)) fit well in the range stated by Santiago and Farina, further supporting suitability of the expression 
1 used in the study.

2

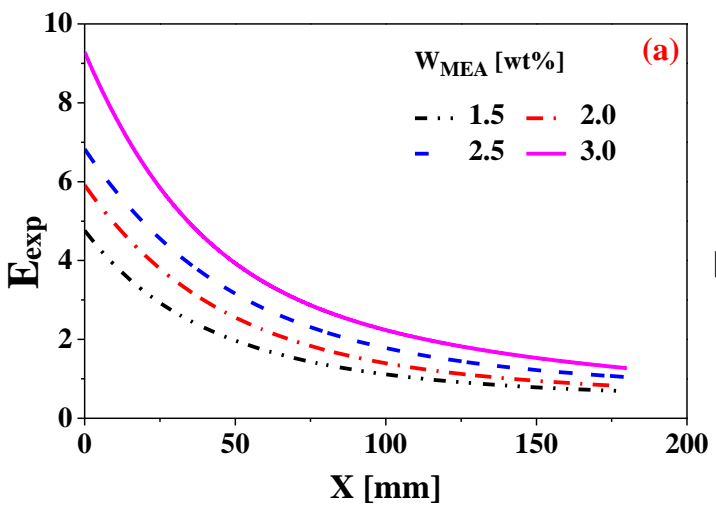

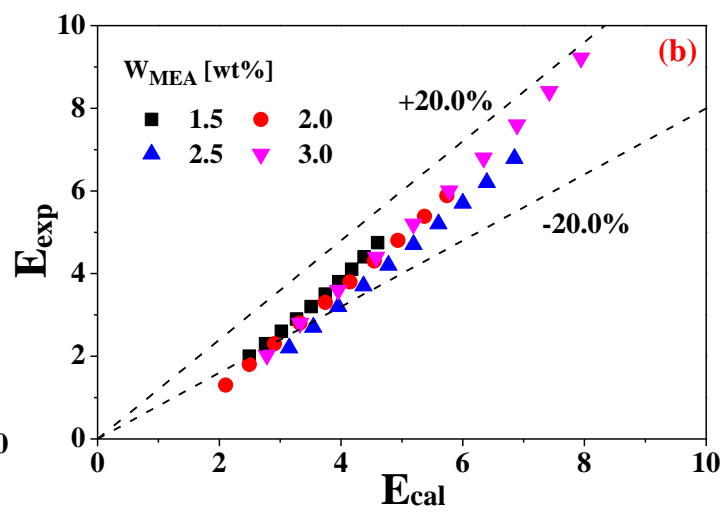

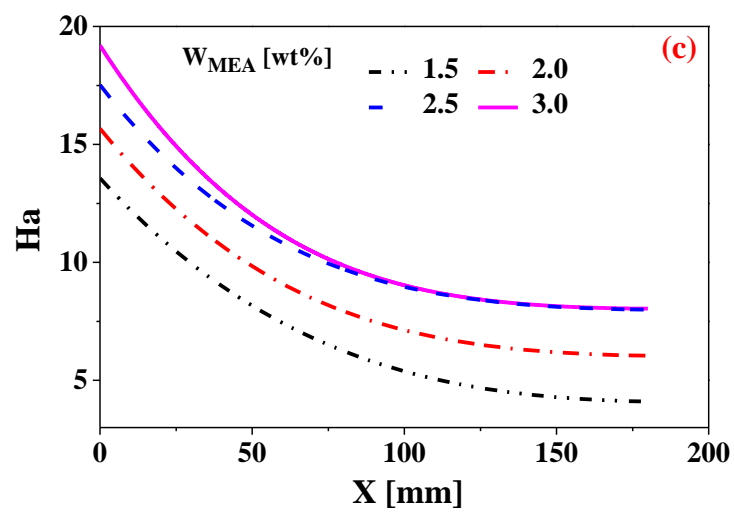

3

Figure 13. The effects of MEA content on $E$ in a unit cell along the serpentine microchannel (a), prediction of $\mathrm{E}(\mathrm{b})$ and $\mathrm{Ha}$ (c) for $\mathrm{CO}_{2}$-MEA system at $25{ }^{\circ} \mathrm{C}, 1.0$ atm $\mathrm{Q}_{\mathrm{G}}=5 \mathrm{~mL} / \mathrm{min}$ and $\mathrm{Q}_{\mathrm{L}}=1 \mathrm{~mL} / \mathrm{min}$.

\subsection{Empirical Correlations for Mass Transfer Performance}

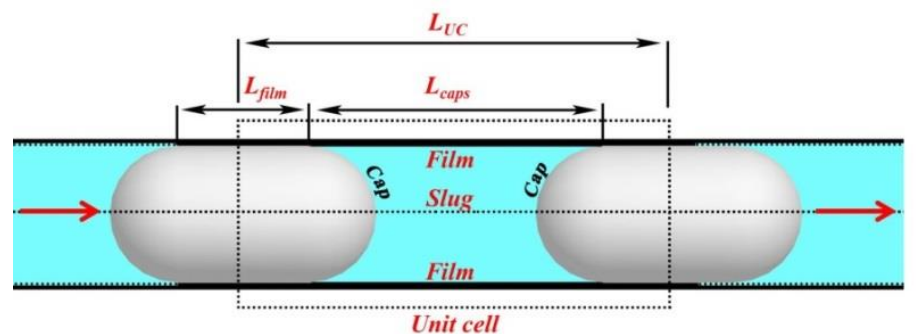

Figure 14. Schematic overview of unit cell, bubble, slug and film.

In order to further investigate and predict the mass transfer of the unit cells detailedly, the improved mass transfer model proposed by van Baten and Krishna, ${ }^{16}$ was introduced to verify experimental data. The core principle of the model was that 
1 the contributions from caps $\left(k_{L} a\right)_{\text {caps }}$ and film $\left(k_{L} a\right)_{\mathrm{f}}$ to mass transfer were evaluated

2 based on Higbie's penetration theory. The improved mass transfer model was shown

3 in the following.

4

$$
\mathrm{k}_{\mathrm{L}} \mathrm{a}=\frac{2 \sqrt{2}}{\pi} \sqrt{\frac{\mathrm{D}_{\mathrm{CO}_{2}} \mathrm{U}_{\mathrm{B}-\mathrm{sat}}}{\mathrm{d}_{\mathrm{H}}}} \frac{4}{\mathrm{~L}_{\mathrm{UC}}}+\frac{2}{\sqrt{\pi}} \sqrt{\frac{\mathrm{D}_{\mathrm{CO}_{2}} \mathrm{U}_{\mathrm{B}-\mathrm{sat}}}{\varepsilon_{\mathrm{V}} \mathrm{L}_{\mathrm{UC}}}} \frac{4 \varepsilon_{\mathrm{V}}}{\mathrm{d}_{\mathrm{H}}}
$$

5 where $U_{B-s a t}, \varepsilon_{V}$ and $L_{U C}$ were the difference of the transient bubble velocity and the

6 saturated bubble velocity for absorption equilibrium state, the gas void fraction based

7 on the unit cell volume and the unit cell length, respectively.

8 It was well known that the basic assumption of van Baten's model (Eq. (33)) was 9 the ideal mixing in the liquid slug for a unit cell. Actually, there was a big concentration distribution in the liquid slug, ${ }^{52}$ so van Baten's model was difficult to accurately predict the experimental data of this work. Considering that the deviation mainly originated from the non-ideal mixing in the liquid slug by mass exchange with the liquid film layer close to the wall, a correction term in the form of Eq. (34) was proposed.

$$
\left(\mathrm{k}_{\mathrm{L}} \mathrm{a}\right)_{\mathrm{C}}=\frac{3.66 \mathrm{D}_{\mathrm{CO}_{2}}}{\mathrm{~d}_{\mathrm{H}}} \frac{\mathrm{L}_{\mathrm{S}}\left(\mathrm{d}_{\mathrm{H}}-2 \delta\right)}{\mathrm{d}_{\mathrm{H}}^{2} \mathrm{~L}_{\mathrm{UC}}}
$$

This mass exchange between the slug and liquid film layer could be approximated under-developed laminar flow in a circular channel with a constant boundary, ${ }^{53,54}$ as well as considering the ratio of the slug length to the unit cell length. The above correlation was derived from the classical theory, where the caps were assumed perfectly spherical and the film was annular due to the circular capillary in van Baten's model. Compared to the non-spherical caps and the non-annular film due to 
1 the square microchannel in this work, it was necessary to modify the parameters in

2 order to fit the experimental data, as shown in Table 3.

3 As shown in Eq. (34), $\left(k_{L}\right)_{C}$ is set as $3.66 \mathrm{D}_{\mathrm{CO} 2} / \mathrm{d}_{\mathrm{H}}$ since the film-slug exchange is

4 initially simplified as flowing in a circular channel with fully developed laminar flow.

5 Thus, underdeveloped laminar flow in the liquid film and different thickness of the

6 liquid film in the cross section require the modification of ideal $\left(k_{L}\right)_{C}$. In this case, the

7 additional constant is added to the semi-empirical correlation according to the

8 experimental data.

9 The validity of the models for both $\mathrm{CO}_{2}-\mathrm{H}_{2} \mathrm{O}$ and $\mathrm{CO}_{2}$-MEA systems are shown in

Figures $15 \& 16$, respectively. The predicted values were well aggreement with the experimental results for a deviation of $\pm 25 \%$. Applying the model for $\mathrm{CO}_{2}-\mathrm{H}_{2} \mathrm{O}$ system to $\mathrm{CO}_{2}$-MEA system, the net physical mass transfer coefficient could be approximately separated from chemical absorption process.

The basic assumption of van Baten's model was the ideal mixing in the liquid slug for a unit cell without concentration gradient, where the overall mass transfer coefficient of the unit cell could be considered as the sum of the overall mass transfer coefficients from two caps and the film, $k_{L} a=\left(k_{L} a\right)_{\text {caps }}+\left(k_{L} a\right)_{\mathrm{f}}$. This was inconsistent with the situation where concentration difference existed between the film and the bulk liquid slug, and the mass exchange was mainly determined by the internal circulation in the bulk liquid slug. This is believed to be the main reason for the inconsistence shown in Figures 15 and 16 for fitting the correlations (Table 3) with the measured data. More experimental data are shown in Figure S7 \& S8 of SI. 
1

\begin{tabular}{|c|c|c|c|c|}
\hline System & $\left(\mathrm{k}_{\mathrm{L}} \mathrm{a}\right)_{\text {caps }}(1 / \mathrm{s})$ & $\left(k_{L} a\right)_{\text {film }}(1 / s)$ & $\left(\mathrm{k}_{\mathrm{L}} \mathrm{a}\right)_{\mathrm{C}}(1 / \mathrm{s})$ & $\mathbf{R}^{2}$ \\
\hline $\mathrm{H}_{2} \mathrm{O}-\mathrm{CO}_{2}$ & $\frac{1.4 \sqrt{2}}{\pi} \sqrt{\frac{\mathrm{D}_{\mathrm{CO}_{2}} \mathrm{U}_{\text {B-sat }}}{\mathrm{d}_{\mathrm{H}}}} \frac{4}{\mathrm{~L}_{\mathrm{UC}}}$ & $\frac{5.4}{\sqrt{\pi}} \sqrt{\frac{\mathrm{D}_{\mathrm{CO}_{2}} \mathrm{U}_{\text {B-sat }}}{\varepsilon_{\mathrm{v}} \mathrm{L}_{\mathrm{UC}}}} \frac{4 \varepsilon_{\mathrm{v}}}{\mathrm{d}_{\mathrm{H}}}$ & $-13 \frac{3.66 \mathrm{D}_{\mathrm{CO}_{2}}}{\mathrm{~d}_{\mathrm{H}}} \frac{\mathrm{L}_{\mathrm{S}}\left(\mathrm{d}_{\mathrm{H}}-2 \delta\right)}{\mathrm{d}_{\mathrm{H}}^{2} \mathrm{~L}_{\mathrm{UC}}}$ & 0.95 \\
\hline $\mathrm{MEA}-\mathrm{CO}_{2}$ & $\frac{\sqrt{2}}{\pi} \sqrt{\frac{\mathrm{D}_{\mathrm{CO}_{2}} \mathrm{U}_{\mathrm{B}-\mathrm{sat}}}{\mathrm{d}_{\mathrm{H}}}} \frac{4}{\mathrm{~L}_{\mathrm{UC}}}$ & $\frac{7.4}{\sqrt{\pi}} \sqrt{\frac{\mathrm{D}_{\mathrm{CO}_{2}} \mathrm{U}_{\text {B-sat }}}{\varepsilon_{\mathrm{v}} \mathrm{L}_{\mathrm{UC}}}} \frac{4 \varepsilon_{\mathrm{v}}}{\mathrm{d}_{\mathrm{H}}}$ & $-35 \frac{3.66 \mathrm{D}_{\mathrm{CO}_{2}}}{\mathrm{~d}_{\mathrm{H}}} \frac{\mathrm{L}_{\mathrm{S}}\left(\mathrm{d}_{\mathrm{H}}-2 \delta\right)}{\mathrm{d}_{\mathrm{H}}^{2} \mathrm{~L}_{\mathrm{UC}}}$ & 0.96 \\
\hline
\end{tabular}

2
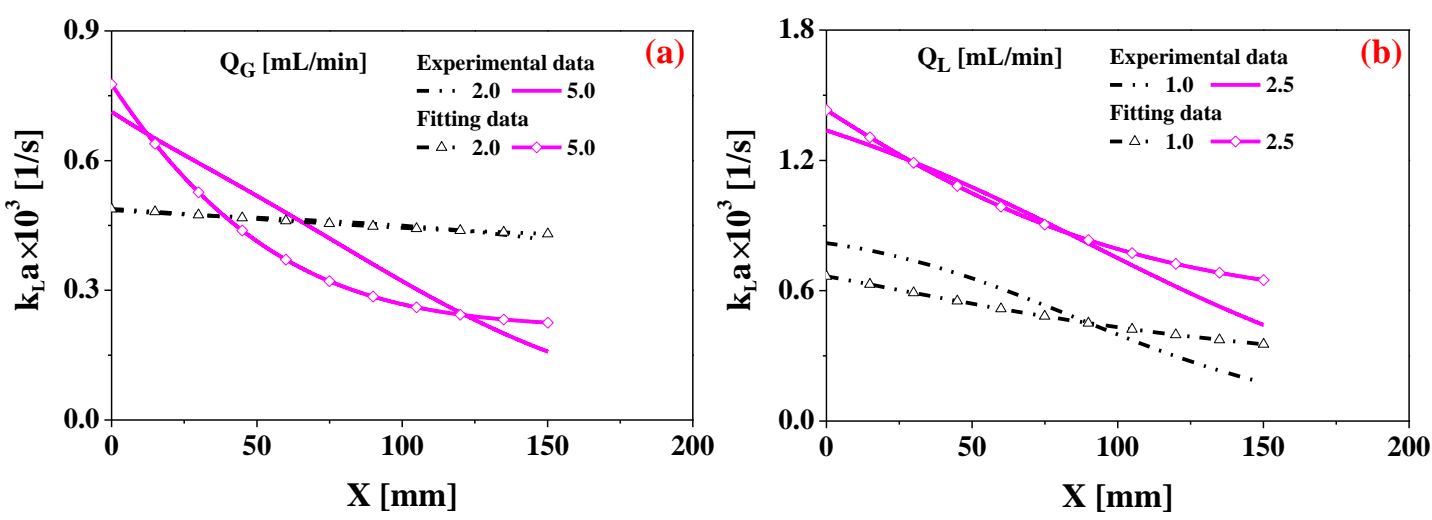

$4 \quad$ Figure 15. Prediction of overall mass transfer coefficients for $\mathrm{CO}_{2}-\mathrm{H}_{2} \mathrm{O}$ system at 25 ${ }^{\circ} \mathrm{C}, 1.0$ atm for $(\mathrm{a}) \mathrm{Q}_{\mathrm{L}}=1 \mathrm{~mL} / \mathrm{min}$, and (b) $\mathrm{Q}_{\mathrm{G}}=5.5 \mathrm{~mL} / \mathrm{min}$.
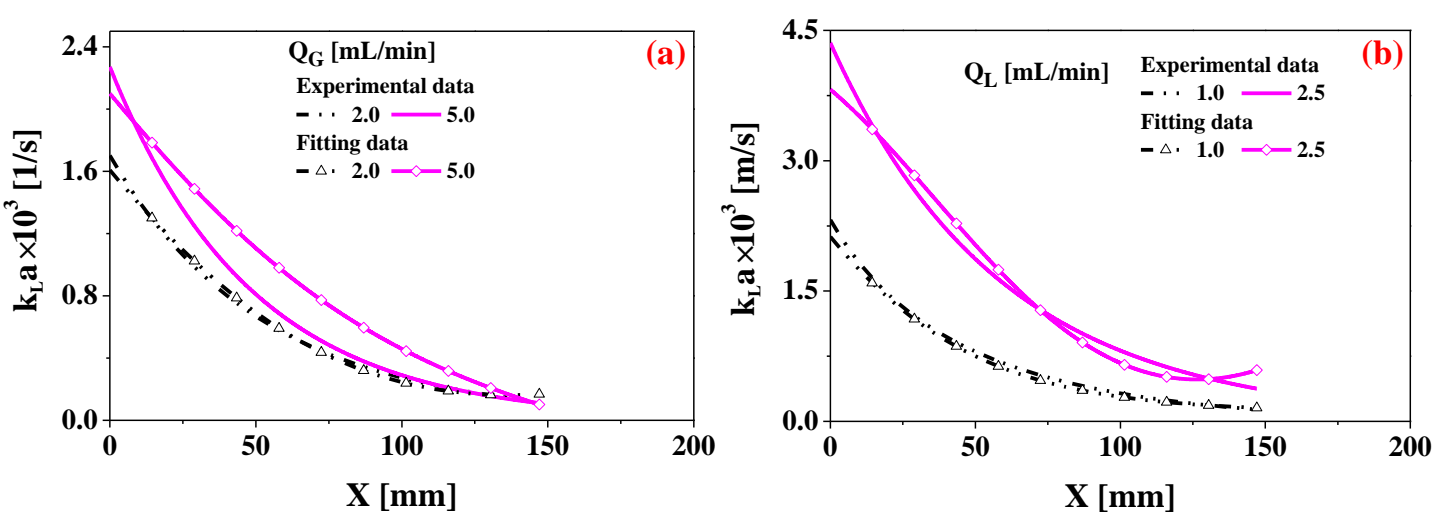

Figure 16. Prediction of overall mass transfer coefficients for $\mathrm{CO}_{2}-\mathrm{MEA}$ system at 25

${ }^{\circ} \mathrm{C}, 1.0 \mathrm{~atm}$ and $W_{\mathrm{MEA}}=1 \mathrm{wt} \%$ for (a) $\mathrm{Q}_{\mathrm{L}}=1 \mathrm{~mL} / \mathrm{min}$, and (b) $\mathrm{Q}_{\mathrm{G}}=5.5 \mathrm{~mL} / \mathrm{min}$.

As analyzed above, the semi-empirical correlations were proposed to predict the physical/chemical mass transfer coefficients in the $\mathrm{CO}_{2}-\mathrm{H}_{2} \mathrm{O}$ system. If the range of the parameters in the empirical correlation is reasonably wide to adapt the situation of 
1 chemical mass transfer coefficient, the enhancement factor can be estimated. It should

2 be noted that the semi-empirical correlations may not be suitable when beyond the

3 scope of the experimental conditions. For the $\mathrm{CO}_{2}$-MEA system, the semi-empirical

4 correlation indeed reflects the effect of only an overall mass transfer coefficient

5 covering both mass transfer and chemical reactions. This is mainly due to the fact that

6 they are impractically measureable separately in the dynamic physical/chemical

7 coupling process, although approximate solutions may be obtained through numerical

8 analysis. The development in this work with in-situ measurements along

9 microchannels provides a practical approach to quantify the parameters in order to

10 estimate the overall apparent mass transfer coefficient in the $\mathrm{CO}_{2}$-MEA system, which

11 is still difficult in the macroscale system. It can also be considered as a benchmark for

12 estimating the enhancement factor of other physical/chemical coupling systems

13 having different kinetics, such as $\mathrm{CO}_{2}$-DEA and $\mathrm{CO}_{2}$-MDEA. Nevertheless, by

14 incorporating a wider variety of experimental data a simpler empirical correlation

15 may be established for determining the enhancement factor. This is under active

16 investigation in our laboratories.

\section{5. CONCLUSIONS}

18 Dynamic coupling of mass transfer and chemical reaction during Taylor flow in

19 serpentine microchannels was experimentally characterized by an online method. The

20 dynamic changes of gas bubbles, and key mass transfer parameters including $k_{L} a, k_{L}$

21 and $a$ were measured or calculated under the optimized experimental conditions (i.e.,

$\left.22 Q_{G}, Q_{L}, W_{M E A}\right)$, respectively. The dynamic enhancement of mass transfer by chemical 
1 reaction was further quantified in terms of $E$. Based on the experimental results, a

2 modified van Baten's model was proposed to predict mass transfer performance for

3 both $\mathrm{CO}_{2}-\mathrm{H}_{2} \mathrm{O}$ and $\mathrm{CO}_{2}-\mathrm{MEA}$ systems and the $\mathrm{R}^{2}$ values were 0.95 and 0.96 ,

4 respectively.

5 Overall, the dynamic shrinkage of Taylor bubbles flowing along the microchannel

6 was observed, showing more significant changes in $\mathrm{CO}_{2}$-MEA system. Three stages

7 of the shrinkage of Taylor bubbles were observed, where about $70 \%$ of the length

8 reduction took place in the first stage, and lower change rates in other stages,

9 indicating the dynamic impact of the fast chemical reaction. Compared to $\mathrm{CO}_{2}-\mathrm{H}_{2} \mathrm{O}$

10 system, $k_{L} a$ was considerably intensified due to chemical reaction for $\mathrm{CO}_{2}-\mathrm{MEA}$

11 system. The dynamic decrease and experiencing three stages of $k_{L} a$ in a unit cell was

12 also found along the microchannel for $\mathrm{CO}_{2}$-MEA system, where $k_{L} a$ in the first stage

13 reached approximately $70 \%$. $k_{L}$ also decreased sharply as Taylor bubbles moved

14 downstream along the microchannel for $\mathrm{CO}_{2}$-MEA system. For a given liquid flow

15 rate, the decreasing curves of $k_{L}$ along the microchannel for different gas flow rates

16 crossed at a critical position, indicating the interplay between the effects of chemical

17 reactions and the physical shape of bubbles.

18 Finally, the dimensionless correlations on the mass transfer performance for both

$19 \mathrm{CO}_{2}-\mathrm{H}_{2} \mathrm{O}$ and $\mathrm{CO}_{2}$-MEA systems showed that the calculated values agreed well with

20 the experimental results and the experimental results for a deviation of $\pm 25 \%$,

21 demonstrating the feasibility of the model for predicting key mass transfer parameters.

22 The correlations also suggested the net physical mass transfer performance in 
$1 \mathrm{CO}_{2}$-MEA system could be reasonably separated from the chemical absorption

2 process.

\section{6. SUPPORTING INFORMATION}

4 Experimental data under other operating conditions, the derivation process of Eq. 5,

5 Eq. 15 and Eq. 34 are shown in Supporting Information.

\section{7. ACKNOWLEDGMENTS}

7 We gratefully acknowledge the financial supports from National Natural Science

8 Foundation of China (Nos. 21978250, 21808194), Natural Science Foundation of

9 Shandong Province (ZR2017BB058) and Key Technology Research and

10 Development Program of Shandong (2019JZZY010410).

\section{NOMENCLATURE}

$$
\begin{array}{ll}
\mathrm{a} & =\text { specific surface area }\left(\mathrm{m}^{-1}\right) \\
\mathrm{A}_{\mathrm{s}} & =\text { gas bubble surface area in a unit cell }\left(\mathrm{m}^{2}\right) \\
\mathrm{C}_{\mathrm{CO}_{2}} & =\mathrm{CO}_{2} \text { concentration in liquid phase }\left(\mathrm{mol} \cdot \mathrm{m}^{-3}\right) \\
\mathrm{C}_{\mathrm{CO}_{2}}^{*} \mathrm{~L} & =\text { saturated solubility of } \mathrm{CO}_{2} \text { in liquid phase }\left(\mathrm{mol} \cdot \mathrm{m}^{-3}\right) \\
\mathrm{C}_{\mathrm{CO}} & =\mathrm{CO}_{2} \text { concentration in liquid phase }\left(\mathrm{mol} \cdot \mathrm{m}^{-3}\right) \\
\mathrm{C}_{\mathrm{CO}_{2}, \mathrm{i}} & =\mathrm{CO}_{2} \text { concentration at gas-liquid interface }\left(\mathrm{mol} \cdot \mathrm{m}^{-3}\right) \\
\mathrm{C}_{\mathrm{MEA}} & =\text { MEA concentration in liquid phase }\left(\mathrm{mol} \cdot \mathrm{m}^{-3}\right) \\
\mathrm{C}_{\mathrm{MEA}, \mathrm{L}} & =\text { MEA concentration in the bulk liquid phase }\left(\mathrm{mol} \cdot \mathrm{m}^{-3}\right) \\
\mathrm{C}_{\mathrm{MEA}, 0} & =\text { initial MEA concentration in liquid phase }\left(\mathrm{mol} \cdot \mathrm{m}^{-3}\right) \\
\mathrm{d}_{\mathrm{H}} & =\text { microchannel hydraulic diameter }(\mathrm{m}) \\
\mathrm{D}_{\mathrm{CO}} & =\text { diffusion coeffcient of } \mathrm{CO} \mathrm{O}_{2} \text { in aqueous MEA solution }\left(\mathrm{m}^{2} \cdot \mathrm{s}^{-1}\right) \\
\mathrm{D}_{\mathrm{MEA}} & =\text { diffusion coeffcient of } \mathrm{MEA} \text { in aqueous MEA solution }\left(\mathrm{m}^{2} \cdot \mathrm{s}^{-1}\right)
\end{array}
$$




$$
\begin{aligned}
& \mathrm{E} \quad=\text { enhancement factor } \\
& \mathrm{E}_{\infty} \quad=\text { infinite enhancement factor } \\
& \mathrm{H}_{\mathrm{CO}_{2}}^{\text {loaded }}=\text { Henry's constant of } \mathrm{CO}_{2} \text { in the loaded liquid phase }\left(\mathrm{kPa}^{3} \mathrm{~mol}^{-1}\right) \\
& \mathrm{H}_{\mathrm{N}_{2} \mathrm{O}}^{\text {loaded }}=\text { Henry's constant of } \mathrm{N}_{2} \mathrm{O} \text { in the loaded liquid phase }\left(\mathrm{kPam}^{3} \cdot \mathrm{mol}^{-1}\right) \\
& \mathrm{H}_{\mathrm{CO}_{2}}^{\mathrm{H}_{2} \mathrm{O}}=\text { Henry's constant of } \mathrm{CO}_{2} \text { in water }\left(\mathrm{kPam}^{3} \cdot \mathrm{mol}^{-1}\right) \\
& \mathrm{H}_{\mathrm{N}_{2} \mathrm{O}}^{\mathrm{H}_{2} \mathrm{O}}=\mathrm{N}_{2} \mathrm{O} \text { Henry's constant in water }\left(\mathrm{kPa}^{3}{ }^{3} \mathrm{~mol}^{-1}\right) \\
& \mathrm{H}_{\mathrm{N}_{2} \mathrm{O}}^{\mathrm{MEA}}=\mathrm{N}_{2} \mathrm{O} \text { Henry's constant in } \operatorname{MEA}\left(\mathrm{kPa}^{3} \cdot \mathrm{mol}^{-1}\right) \\
& \Delta \mathrm{H}_{\mathrm{N}_{2} \mathrm{O}}^{\text {unlead }}=\text { Henry's constant deviation of } \mathrm{N}_{2} \mathrm{O} \text { in unloaded liquid }\left(\mathrm{kPa}^{3} \cdot \mathrm{mol}^{-1}\right) \\
& \Delta \mathrm{H}_{\mathrm{N}_{2} \mathrm{O}}^{\text {loaded }}=\text { Henry's constant deviation of } \mathrm{N}_{2} \mathrm{O} \text { in loaded liquid }\left(\mathrm{kPa}^{3} \mathrm{~mol}^{-1}\right) \\
& \text { I }=\text { radius of the quadrant at the corner }(\mathrm{m}) \\
& \mathrm{k}_{1} \quad=\text { second-order reaction rate constant }\left(\mathrm{m}^{3} \cdot \mathrm{mol}^{-1} \cdot \mathrm{s}^{-1}\right) \\
& \mathrm{k}_{\mathrm{L}} \quad=\text { liquid side mass transfer coefficient }\left(\mathrm{m} \cdot \mathrm{s}^{-1}\right) \\
& \mathrm{k}_{\mathrm{L}}^{0} \quad=\text { liquid side physical mass transfer coefficient }\left(\mathrm{m} \cdot \mathrm{s}^{-1}\right) \\
& \mathrm{L}_{\mathrm{B}} \quad=\quad \text { Taylor bubble length }(\mathrm{m}) \\
& \mathrm{L}_{\text {caps }} \quad=\text { length of liquid slug and two caps }(\mathrm{m}) \\
& \mathrm{L}_{\text {film }} \quad=\text { liquid film length }(\mathrm{m}) \\
& \mathrm{L}_{\mathrm{S}} \quad=\text { liquid slug length }(\mathrm{m}) \\
& \mathrm{L}_{\mathrm{UC}} \quad=\text { unit cell length }(\mathrm{m}) \\
& \mathrm{m}_{\mathrm{MEA}}=\text { mole fraction of MEA in aqueous MEA solution }(\mathrm{mol} \%) \\
& \mathrm{m}_{\mathrm{H}_{2} \mathrm{O}}=\text { mole fraction of MEA in aqueous MEA solution }(\mathrm{mol} \%) \\
& \mathrm{M}_{\mathrm{MEA}}=\text { molecular mass of } \operatorname{MEA}\left(\mathrm{kg} \cdot \mathrm{mol}^{-1}\right) \\
& \mathrm{M}_{\mathrm{H}_{2} \mathrm{O}}=\text { molecular mass of } \mathrm{H}_{2} \mathrm{O}\left(\mathrm{kg} \cdot \mathrm{mol}^{-1}\right) \\
& \mathrm{P}_{\mathrm{CO}_{2}} \quad=\text { gas phase pressure }(\mathrm{Pa}) \\
& \mathrm{r}_{\mathrm{CO}_{2}}=\mathrm{CO}_{2} \text { absorption rate in aqueous MEA solution }\left(\mathrm{mol} \cdot \mathrm{m}^{-3} \cdot \mathrm{s}^{-1}\right) \\
& \mathrm{R} \quad=\operatorname{gas} \text { constant }(8.3145 \mathrm{~J} /(\mathrm{mol} \cdot \mathrm{K})) \\
& \mathrm{t}=\text { solution temperature }\left({ }^{\circ} \mathrm{C}\right) \\
& \mathrm{T}=\text { operating temperature }(\mathrm{K}) \\
& \mathrm{U}_{\mathrm{B}} \quad=\text { gas bubble velocity }\left(\mathrm{m} \cdot \mathrm{s}^{-1}\right) \\
& \mathrm{U}_{\mathrm{B}-\mathrm{sat}}=\text { the difference between the transient bubble velocity and the saturated } \\
& =\text { bubble velocity for absorption equilibrium state }\left(\mathrm{m} \cdot \mathrm{s}^{-1}\right)
\end{aligned}
$$


1 Greek Symbols

$\alpha=$ loading of $\mathrm{CO}_{2}\left(\mathrm{~mol}_{\mathrm{CO}_{2}} / \mathrm{mol}_{\mathrm{MEA}}\right)$

$\gamma_{\mathrm{H}_{2} \mathrm{O}}=$ surface tension of pure water $\left(\mathrm{N} \cdot \mathrm{m}^{-1}\right)$

$\gamma_{\text {MEA }}=$ surface tension of pure MEA $\left(\mathrm{N} \cdot \mathrm{m}^{-1}\right)$

$\gamma_{\mathrm{TP}} \quad=$ gas-liquid interfacial tension $\left(\mathrm{N} \cdot \mathrm{m}^{-1}\right)$

$\delta=\quad=$ liquid film thickness near the channel wall center $(\mathrm{m})$

$\varepsilon_{\mathrm{V}} \quad=$ gas void fraction based on the unit cell volume

$\mu_{\mathrm{L}} \quad=$ aqueous MEA solution viscosity (Pa.s)

$\mu^{\text {unloaded }}=$ aqueous MEA solution viscosity without $\mathrm{CO}_{2}(\mathrm{~Pa} \cdot \mathrm{s})$

$\mu_{\mathrm{MEA}} \quad=$ viscosity of MEA $(\mathrm{Pa} \cdot \mathrm{s})$

$\mu_{\mathrm{H}_{2} \mathrm{O}} \quad=\quad$ viscosity of water $(\mathrm{Pa} \cdot \mathrm{s})$

$\rho_{\mathrm{H}_{2} \mathrm{O}} \quad=$ density of $\mathrm{H}_{2} \mathrm{O}\left(\mathrm{kg} \cdot \mathrm{m}^{-3}\right)$

$\rho_{\mathrm{L}} \quad=$ density of aqueous MEA solution $\left(\mathrm{kg} \cdot \mathrm{m}^{-3}\right)$

$\rho_{\mathrm{MEA}} \quad=$ density of MEA $\left(\mathrm{kg} \cdot \mathrm{m}^{-3}\right)$

$\varphi_{\mathrm{H}_{2} \mathrm{O}} \quad=$ volume fraction of $\mathrm{H}_{2} \mathrm{O}$

$\varphi_{\mathrm{MEA}}=$ volume fraction of MEA

$\Phi=\quad \begin{aligned} & \text { bubble sphericity (the ratio of the surface area of a sphere to the } \\ & \text { surface area of a gas bubble with the }\end{aligned}$

2 Dimensionless Parameters

$\mathrm{Ca}=$ capillary number $\left(\mathrm{Ca}=\left(\mu_{\mathrm{L}} \mathrm{U}_{\mathrm{B}}\right) / \gamma_{\mathrm{L}}\right)$

$\mathrm{Ha}=$ Hatta number $\left(\mathrm{Ha}=\sqrt{\mathrm{D}_{\mathrm{CO}_{2}} \mathrm{k}_{1} \mathrm{C}_{\mathrm{MEA}, \mathrm{L}}} / \mathrm{k}_{\mathrm{L}}^{0}\right)$ 


\section{REFERENCES}

(1) Mandal, B. P.; Biswas, A. K.; Bandyopadhyay, S. S. Absorption of carbon dioxide into aqueous blends of 2-amino-2-methyl-1-propanol and diethanolamine. Chem. Eng. Sci. 2003, 58(18), 4137-4144.

(2) Maceiras, R.; Álvarez, E.; Cancela, M. Á. Effect of temperature on carbon dioxide absorption in monoethanolamine solutions. Chem. Eng. J. 2008, 138(1-3), 295-300.

(3) Kashid, M. N.; Renken, A.; Kiwi-Minsker, L., Gas-liquid and liquid-liquid mass transfer in microstructured reactors. Chem. Eng. Sci. 2011, 66(17), 3876-3897.

(4) Ye, C. B.; Chen, G. W.; Yuan, Q. Process characteristics of $\mathrm{CO}_{2}$ absorption by aqueous monoethanolamine in a microchannel reactor. Chin. J. Chem. Eng. 2012, 20(1), 111-119.

(5) Metz, B.; Davidson, O.; Coninck, H. D.; Loos, M.; Meyer, L. Carbon Dioxide Capture and Storage; Cambridge Univ Press, UK, 2005.

(6) Luo, X.; Hartono. A.; Hussain, S.; Svendsen, H. F. Mass transfer and kinetics of carbon dioxide absorption into loaded aqueous monoethanolamine solutions. Chem. Eng. Sci. 2015, 123, 57-69.

(7) Kobayashi, J.; Mori, Y.; Okamoto, K.; Akiyama, R.; Ueno, M.; Kitamori, T.; Kobayashi, S. A microfluidic device for conducting gas-liquid-solid hydrogenation reactions. Science 2004, 304(5675), 1305-1308.

(8) Fu, T. T.; Ma, Y. G.; Funfschilling, D.; Li, H. Z. Bubble formation and breakup mechanism in a microfluidic flow-focusing device. Chem. Eng. Sci. 2009, 64(10), 2392-2400.

(9) Sobieszuk, P.; Pohorecki, R.; Cyganski, P.; Grzelka, J. Determination of the interfacial area and mass transfer coefficients in the Taylor gas-liquid flow in a microchannel. Chem. Eng. Sci. 2011, 66(23), 6048-6056.

(10) Yang, L.; Tan, J.; Wang, K.; Luo, G. S. Mass transfer characteristics of bubbly flow in microchannels. Chem. Eng. Sci. 2014, 109(16), 306-314.

(11) Li, L.; Yao, C. Q.; Jiao, F. J.; Han, M.; Chen, G. W. Experimental and kinetic study of the nitration of 2-ethylhexanol in capillary microreactors. Chem. Eng. Process. 2017, 117, 179-185.

(12) Abiev, R. Sh.; Svetlov, S.; Hasse, S. Hydrodynamics and mass transfer of gas-liquid and liquid-liquid Taylor flow in microchannels. Chem. Eng. Technol. 2017, 40(11), 1985-1998.

(13) Yao, C. Q.; Zhao, Y. C.; Chen, G. W. Multiphase processes with ionic liquids in microreactors: hydrodynamics, mass transfer and applications. Chem. Eng. Sci. 2018, 189, 340-359.

(14) Zhang, P.; Yao, C. Q.; Ma, H. Y.; Jin, N.; Zhang, X. L.; Lv, H. Y.; Zhao, Y. C. Dynamic changes in gas-liquid mass transfer during Taylor flow in long serpentine square microchannels. Chem. Eng. Sci. 2018, 182, 17-27.

(15) Berčič, G.; Pintar, A. The role of gas bubbles and liquid slug lengths on mass transport in the Taylor flow through capillaries. Chem. Eng. Sci. 1997, 52(21-22), 3709-3719.

(16) van Baten, J. M. V.; Krishna, R. CFD simulations of mass transfer from Taylor bubbles rising in circular capillaries. Chem. Eng. Sci. 2004, 59(12), 2535-2545.

(17) Yue, J.; Chen, G. W.; Yuan, Q.; Luo, L. A.; Gonthier, Y. Hydrodynamics and mass transfer characteristics in gas-liquid flow through a rectangular microchannel. Chem. Eng. Sci. 2007, 62(7), 2096-2108.

(18) Yue, J.; Luo, L. A.; Gonthier, Y.; Chen, G. W.; Yuan, Q. An experimental study of air-water 
Taylor flow and mass transfer inside square microchannels. Chem. Eng. Sci. 2009, 64, 3697-3708. (19) Li, C. F.; Zhu, C. Y.; Ma, Y. G.; Liu, D. Z.; Gao, X. Q. Experimental study on volumetric mass transfer coefficient of $\mathrm{CO} 2$ absorption into MEA aqueous solution in a rectangular microchannel reactor. Int. J. Heat Mass Transf. 2014, 78, 1055-1059.

(20) Chu, C. Y.; Zhang, F. B.; Zhu, C. Y.; Fu, T. T.; Ma, Y. G. Mass transfer characteristics of $\mathrm{CO}_{2}$ absorption into 1-butyl-3-methylimidazolium tetrafluoroborate aqueous solution in microchannel. Int. J. Heat. Mass. Transfer. 2019, 128, 1064-1071.

(21) Cubaud, T.; Sauzade, M.; Sun, R. P. $\mathrm{CO}_{2}$ dissolution in water using long serpentine microchannels. Biomicrofluidics 2012, 6(2), 220020-220029.

(22) Sun, R. P.; Cubaud, T. Dissolution of carbon dioxide bubbles and microfluidic multiphase flows. Lab Chip 2011, 11(17), 2924-2928.

(23) Abolhasani, M.; Singh, M.; Kumacheva, E.; Günther, A. Automated microfluidic platform for studies of carbon dioxide dissolution and solubility in physical solvents. Lab Chip 2012, 12(9), $1611-1618$.

(24) Tan, J.; Lv- Y. C.; Xu, J. H.; Luo, G. S. Mass transfer performance of gas-liquid segmented flow in microchannels. Chem. Eng. J. 2012, 181-182, 229-235.

(25) Yao, C. Q.; Dong, Z. Y.; Zhao, Y. C.; Chen, G. W. An online method to measure mass transfer of slug flow in a microchannel. Chem. Eng. Sci. 2014, 112, 15-24.

(26) Zhu, C. Y.; Li, C. F.; Gao, X. Q.; Ma, Y. G.; Liu, D. Z. Taylor flow and mass transfer of $\mathrm{CO}_{2}$ chemical absorption into MEA aqueous solutions in a T-junction microchannel. Int. J. Heat Mass Transfer. 2014, 73(7), 492-499.

(27) Zhu, C. Y.; Lu, Y. T.; Fu, T. T.; Ma, Y. G.; Li, H. Z. Experimental investigation on gas-liquid mass transfer with fast chemical reaction in microchannel. Int. J. Heat Mass Transfer 2017, 114, 83-89.

(28) Caplow, M. Kinetics of carbamate formation and breakdown. J. Am. Chem. Soc. 1968, 90, 6795-6803.

(29) Danckwerts, P. V. The reaction of $\mathrm{CO}_{2}$ with ethanolamines. Chem. Eng. Sci. 1979, 34(4), 443-446.

(30) Crooks, J. E.; Donnellan, J. P. Kinetics and mechanism of the reaction between carbon dioxide and amines in aqueous solution. J. Chem. Soc. Perkin Trans. 1989, 2(4), 331-333.

(31) da Silva, E. F.; Svendsen, H. F. Ab initio study of the reaction of carbamate formation from $\mathrm{CO}_{2}$ and alkanolamines. Ind. Eng. Chem. Res. 2004, 43(13), 3413-3418.

(32) Hagewiesche, D. P.; Ashour, S. S.; Al-Ghawas, H. A.; Sandall, O. C. Absorption of carbon dioxide into aqueous blend of monoethanolamine and N-methyldiethanolamine. Chem. Eng. Sci. 1995, 50(7), 1071-1079.

(33) Horng, S. Y.; Li, M. H. Kinetics of absorption of carbon dioxide into aqueous solutions of monoethanolamine + Triethanolamine. Ind. Eng. Chem. Res. 2002, 41(2), 257-266.

(34) Blauwhoff, P. M. M.; Versteeg, G. F.; Van Swaaij, W. P. M. A study on the reaction between $\mathrm{CO}_{2}$ and alkanolamines in aqueous solutions. Chem. Eng. Sci. 1984, 39(2), 207-225.

(35) Ying, J. R.; Eimer, D. A. Measurements and correlations of diffusivities of nitrous oxide and carbon dioxide in monoethanolamine + water by laminar liquid jet. Ind. Eng. Chem. Res. 2012, 51, $16517-16524$.

(36) van Krevelen, D. W; Hoftijzer, P. J. Kinetics of gas-liquid reactions part I. General theory. Recl. Trav. Chim. Pays-Bas. 1948, 67(7), 563-586. 
(37) Clarke, J. K. A. Kinetics of absorption of cardon dioxide in monoethanolamine solutions at short contact times. Ind. Eng. Chem. Fund. 1964, 3(3), 239-245.

(38) Browning, G. J.; Weiland, R. H. Physical solubility of carbon dioxide in aqueous alkanolamines via nitrous oxide analogy. J. Chem. Eng. Data 1994, 39(4), 817-822.

(39) Diab, F.; Provost, E.; Laloue, N.; Alix, P.; Souchon, V.; Delpoux, O.; Fürst, W. Quantitative analysis of the liquid phase by FT-IR spectroscopy in the system $\mathrm{CO}_{2} /$ diethanolamine (DEA)/ $\mathrm{H}_{2} \mathrm{O}$. Fluid Phase Equilibr. 2012, 325, 90-99.

(40) Chen, Q.; Balaji, S. P.; Ramdin, M.; Gutierrez-Sevillano, J. J.; Bardow, A.; Goetheer, E.; Vlugt, T. J. H. Validation of the $\mathrm{CO}_{2} / \mathrm{N}_{2} \mathrm{O}$ analogy using molecular simulation. Ind. Eng. Chem. Res. 2014, 53(46), 18081-18090.

(41) Hartono, A.; Mba, E. O.; Svendsen, H. F. Physical properties of partially $\mathrm{CO}_{2}$ loaded aqueous monoethanolamine (MEA). J. Chem. Eng. Data 2014, 59(6), 1808-1816.

(42) Versteeg, G. F.; van Swaaij, W. P. M. Solubility and diffusivity of acid gases $\left(\mathrm{CO}_{2}, \mathrm{~N}_{2} \mathrm{O}\right)$ in aqueous alkanolamine solutions. J. Chem. Eng. Data 1988, 33(1), 29-34.

(43) Kasturi, G.; Stepanek, J. B. Two-phase flow-IV. Gas and liquid side mass transfer coefficients. Chem. Eng. Sci. 1974, 29, 1849-1856.

(44) Yao, C. Q.; Dong, Z. Y.; Zhang, Y. C.; Mi, Y.; Zhao, Y. C.; Chen, G. W. On the leakage flow around gas bubbles in slug flow in a microchannel. AIChE J. 2015, 61(11), 3964-3972.

(45) Aussillous, P.; Quéré, D. Quick deposition of a fluid on the wall of a tube. Phys. Fluids 2000, 12(10), 2367-2371.

(46) Vázquez, G.; Alvarez, E.; Navaza, J. M.; Rendo, R.; Romero, E. Surface Tension of Binary Mixtures of Water + Monoethanolamine and Water + 2-Amino-2-methyl-1-propanol and Tertiary Mixtures of These Amines with Water from 25 to $50{ }^{\circ}$ C. J. Chem. Eng. Data 1997, 42(1), 57-59. (47) Shim, S.; Wan, J.; Hilgenfeldt, S.; Panchal, P. D.; Stone, H. A. Dissolution without disappearing: multicomponent gas exchange for $\mathrm{CO}_{2}$ bubbles in a microfluidic channel. Lab Chip 2014, 14(14), 2428-2436.

(48) Dang, M. H.; Yue, J.; Chen, G. W.; Yuan, Q. Formation characteristics of Taylor bubbles in a microchannel with a converging shape mixing junction. Chem. Eng. J. 2013, 223, 99-109.

(49) Tan, J.; Lv, Y. C.; Xu, J. H.; Luo, G. S. Mass transfer characteristic in the formation stage of gas-liquid segmented flow in microchannel. Chem. Eng. J. 2012, 185-186, 314-320.

(50) Hikita, H.; Asai, S.; Ishikawa, H.; Honda, M. The kinetics of reactions of carbon dioxide with monoethanolamine, diethanolamine and triethanolamine by a rapid mixing method. Chem. Eng. J. 1977, 13, 7-12.

(51) Santiago, M.D.; Farina, I.H. Mass transfer with second order reaction-numerical solution. Chem. Eng. Sci. 1970, 25, 744-747.

(52) Butler, C.; Lalanne, B.; Sandmann, K.; Cid, E.; Billet, A. M. Mass transfer in Taylor flow: transfer rate modelling from measurements at the slug and film scale. Int. J. Multiphase Flow 2018, 105, 185-201.

(53) Incropera, F. P.; DeWitt, D. P. Fundamentals of heat and mass transfer; Wiley, USA, 2002.

(54) Das, S. Fundamentals of heat and mass transfer; Alpha Science International Ltd., UK, 2010. 